\title{
Microbiological Assessment of Health-Care Providers in Africa: Systematic Review and Meta-Analysis
}

\section{Authors}

\author{
Abeer B. Idris ${ }^{1,2}$, Alaa B. Idris ${ }^{3}$, Elfatih A. Hasabo ${ }^{4}$, Marwan M. Badawi ${ }^{5}$, Nazar Beirag $^{6}$ \\ *Corresponding author: abeer.babiker89@gmail.com \\ ${ }^{1-}$ Department of Medical Microbiology, Faculty of Medical Laboratory Sciences, University of Khartoum, Khartoum, \\ Sudan \\ ${ }^{2-}$ Department of Agricultural Biotechnology, Faculty of Agriculture, Erciyes University, Kayseri, Turkey \\ ${ }^{3-}$ Faculty of Medicine, University of Bahri, Khartoum, Sudan \\ ${ }^{4-}$ Faculty of Medicine, University of Khartoum, Khartoum, Sudan \\ ${ }^{5-}$ Medical Unit, Higher Academy for Strategic and Security Studies, Alamal Hospital, Khartoum, Sudan \\ ${ }^{6-}$ Biosciences, College of Health, Medicine and Life Sciences, Brunel University, London, Uxbridge, United Kingdom
}

Email addresses of all authors:

ABI, abeer.babiker89@gmail.com

ABI, alaa-babiker@hotmail.com

EAH, alfatehaih@gmail.com

MMB, mmbadawi44new@gmail.com

NB, beirage-89@outlook.com 


\begin{abstract}
Background: Healthcare workers (HCWs) are the safeguards that help prevent illnesses and eliminate them when they occur. This study aimed to scan the related literature and provide pooled data about the level of knowledge/attitude toward infections, vaccination status and infection prevalence among African HCWs to provide better evidence toward specific detailed determination of gaps to strengthen. A total of 11,038 published articles were identified from the search strategy. Among them, 163 articles met our inclusion criteria and passed the quality assessment procedure.
\end{abstract}

Results: The prevalence of HBV was tested for 6,599 African HCWs;6.00\% [95\% Cl; 3.66, 8.33] were positive. The question Are you fully vaccinated against HBV?" was answered by 12,036 HCWs; $43.22 \%$ [95\% Cl; 31.22, 55.21] answered yes. The most crucial local factor identified among respondents for the spread of antimicrobial resistance (AMR) was self-antibiotic prescription $42.00 \%[18.79,65.20]$. The question "Does the infection prevention and control (IPC) guidelines available in your workplace?" was asked to $1,582 \mathrm{HCWs} ; 50.95 \%$ [95\% Cl; 40.22, 61.67] answered yes.

Conclusion: This study determined many weaknesses to be addressed for the sake of improving health in Africa. The current pooled data are critically significant to be implemented in planning governmental or NGOs strategies.

Keywords: Microbiology, Meta-analysis, Healthcare worker, Africa 
medRxiv preprint doi: https://doi.org/10.1101/2021.10.14.21264931; this version posted October 16, 2021. The copyright holder for this preprint (which was not certified by peer review) is the author/funder, who has granted medRxiv a license to display the preprint in perpetuity.

It is made available under a CC-BY-ND 4.0 International license .

\section{Introduction}

Healthcare workers (HCWs) are the safeguards that assist in preventing illnesses and eliminate them when they arise (1). However, the fact that they are a double-edged sword is not to be underestimated (3). When standards go low, safeguards are needed to be saved, and more importantly, they may jeopardize others (4). Several studies indicated that a vast percent of patients (up to $50 \%$ ) are admitted to hospitals after suffering from healthcare- associated infections (5).

Moreover, Africa is considered the continent with the lowest Gross Domestic Product (GDP) as most African countries fall within the lower-middle to low- income countries classification, which could be directly altering continuous education for healthcare workers, weak healthcare infrastructure, application of infection control policies in health facilities and vaccination opportunities against vaccine-preventable diseases for both healthcare workers and the community (7)(8). Furthermore, sub-Saharan Africa accounted for $66 \%$ of the human immunodeficiency viruses (HIV) cases, $68 \%$ of new adult HIV infections, $92 \%$ of new infections in children and $72 \%$ of all acquired immunodeficiency syndrome (AIDS) - related deaths, according to the Joint United Nations Program on HIV/AIDS (UNAIDS) in 2017, while South Africa is the country with the world's most considerable prevalence of people living with HIV as 5.6 million (2). On the other hand and according to the World Health Organization (WHO), the highest prevalence of hepatitis B virus (HBV) infection is reported in the Western Pacific Region, and the African Region as $6.2 \%$ and $6.1 \%$ of the adult population are infected, respectively (9). Furthermore, Sub-Saharan Africa was also identified as having an immense burden of human papillomaviruses (HPV) in the world (24.0\%) (10). Regarding tuberculosis infection (TB), WHO in 2015 identified two African countries 
medRxiv preprint doi: https://doi.org/10.1101/2021.10.14.21264931; this version posted October 16, 2021. The copyright holder for this preprint (which was not certified by peer review) is the author/funder, who has granted medRxiv a license to display the preprint in perpetuity.

It is made available under a CC-BY-ND 4.0 International license .

(Nigeria and South Africa) alongside the other three Asian countries to be responsible for $60 \%$ of incident cases (6).

Many studies have identified infection prevalence, vaccination status, knowledge level, and attitudes among African HCWs regarding various diseases. Therefore, the current systematic review aimed to scan the related literature and provide pooled data about the level of knowledge/Attitude toward infections, vaccination status and infection prevalence among African HCWs to provide better evidence toward specific detailed determination of gaps to strengthen.

\section{Methods}

\subsection{Search strategy}

To identify relevant studies, a systematic review of the literature was conducted on July 1, 2020. The review was conducted following the PRISMA (Preferred Reporting Items for Systematic Reviews and Meta-Analyses) Statement (11). A comprehensive search was conducted in PubMed, Embase, Google Scholar, Scopus, Index Copernicus, DOAJ, EBSCO-CINAHL, Cochrane databases without language limits (studies written in French were later excluded). To obtain current situation evidence, only studies published in or after 2010 were included. Furthermore, all studies where the data collection process took place before 2010 were also excluded. The only exception was if the collection process continued months/years earlier than 2010 and ended in 2010 or afterwards as previously described (12). The keywords used in PubMed was as follow:

((specialists[ti] OR technologists[ti] OR technicians[ti] OR nurses[ti] OR clinicians[ti] OR physicians[ti] OR doctors[ti] OR medical[ti] OR laboratory[ti] OR hospital [ti] OR "health 
medRxiv preprint doi: https://doi.org/10.1101/2021.10.14.21264931; this version posted October 16, 2021. The copyright holder for this preprint (which was not certified by peer review) is the author/funder, who has granted medRxiv a license to display the preprint in perpetuity.

It is made available under a CC-BY-ND 4.0 International license .

personnel"[ti] OR "health staff'[ti] OR healthcare[ti] OR Dentists [ti] OR health[ti]) AND (behavior[ti] OR risk[ti] OR awareness[ti] OR Attitude[ti] OR knowledge[ti] OR assessment[ti] OR evaluation[ti] OR Measure[ti] OR vaccination[ti] OR Prophylaxis[ti] OR screening[ti] OR infection[ti] OR Injury[ti] OR survey[ti] OR Practice[ti] OR surveillance[ti] OR prevalence[ti] OR incidence[ti] OR bacteria[tiab] OR fungi[tiab] OR virus[tiab] OR viral[tiab] OR bacterial[tiab] OR fungal[tiab]) AND (africa[Tiab] OR algeria[Tiab] OR angola[Tiab] OR benin[Tiab] OR botswana[Tiab] OR burkinafaso[Tiab] OR burundi[Tiab] OR caboverde[Tiab] OR cameroon[Tiab] OR central african republic[Tiab] OR CAR[Tiab] OR chad[Tiab] OR comoros[Tiab] OR "democratic republic of the congo"[Tiab] OR "republic of the congo"[Tiab] OR cote d'ivoire[Tiab] OR djibouti[Tiab] OR egypt[Tiab] OR equatorial guinea[Tiab] OR eritrea[Tiab] OR eswatini[Tiab] OR swaziland[Tiab] OR ethiopia[Tiab] OR gabon[Tiab] OR gambia[Tiab] OR ghana[Tiab] OR guinea[Tiab] OR guinea-bissau[Tiab] OR kenya[Tiab] OR lesotho[Tiab] OR liberia[Tiab] OR libya[Tiab] OR madagascar[Tiab] OR malawi[Tiab] OR mali[Tiab] OR mauritania[Tiab] OR mauritius[Tiab] OR morocco[Tiab] OR mozambique[Tiab] OR namibia[Tiab] OR niger[Tiab] OR nigeria[Tiab] OR rwanda[Tiab] OR sao tome principe[Tiab] OR senegal[Tiab] OR seychelles[Tiab] OR sierra leone[Tiab] OR somalia[Tiab] OR south africa[Tiab] OR south sudan[Tiab] OR sudan[Tiab] OR eswatini[Tiab] OR tanzania[Tiab] OR togo[Tiab] OR tunisia[Tiab] OR uganda[Tiab] OR zambia[Tiab] OR zimbabwe[Tiab])).

Moreover, to optimize our search, hand searches of reference lists of included articles were also performed.

\subsection{Study selection and data extraction}

All authors independently assessed titles and abstracts for eligibility, and any disagreement was resolved through discussion. A copy of the full text was obtained for all research articles that were 
medRxiv preprint doi: https://doi.org/10.1101/2021.10.14.21264931; this version posted October 16, 2021. The copyright holder for this preprint (which was not certified by peer review) is the author/funder, who has granted medRxiv a license to display the preprint in perpetuity.

It is made available under a CC-BY-ND 4.0 International license .

available and approved in principle to be included. Abstraction of data was under the task separation method; method and result sections in each study were separately abstracted on different occasions to reduce bias. Moreover, data abstraction was conducted without considering the author's qualifications or expertise (13). When included study gathers groups of health workers and other workers as participants with detailed results for each group; only the health worker participant results will be included, if no detailed results are available, the study will be excluded. If data regarding the period of conduction is missing in a study, the reference list will read and if any cited study is published after 2010, the authors of the current review agreed to predict that the study is conducted after 2010, hence it was considered for inclusion and it was considered to be addressed later in the review as (conducted after 2010) as previously described (12), otherwise the study was excluded. Each research article was screened for relevant information, recorded in the data extraction file (Microsoft Excel). Moreover, data from each method section was extracted using a predefined set of variables, study characteristics, type of participants, study population size, geographical region, and the study conduction period.

\subsection{Assessment of quality}

Each included article was evaluated based on a framework for making a summary assessment of the quality. The related published literature was crossed, then a framework will be structured specifically to determine the level of representativeness of the studied population and to judge the strength of the estimates provided. Six questions are to be answered in each article, and each answer represents either 1 score for yes, 0 score for No or 0 score for not available; A total score for risk of bias and quality was calculated by adding up the scores in all six domains, resulting in a score of between 0 and 6 . The highest score indicates the highest quality. Studies with a score for quality greater or equal to 3 (higher quality) were included in the review as previously described (12). 
medRxiv preprint doi: https://doi.org/10.1101/2021.10.14.21264931; this version posted October 16, 2021. The copyright holder for this preprint (which was not certified by peer review) is the author/funder, who has granted medRxiv a license to display the preprint in perpetuity.

It is made available under a CC-BY-ND 4.0 International license .

The six domains were: is the study objective clearly defined? is the study sample completely determined? is the study population clearly defined and specified? is participants' response rate above $70 \%$, are the methodology and the data analysis used rigorous?.

The Trim and Fill method was used to assess the risk of publication bias in each question response in the included studies (14). Publication bias was evaluated separately for each question-corresponding responses only if the question was addressed and answered in studies equal to or greater than ten.

\subsection{Quantitative analysis}

Meta-analysis was performed - whenever possible using Review Manager Software (Version 5.3). In studies where the Standard Error (SE) is not reported, the following formula was used to calculate it: $\mathrm{SE} \square=\square \sqrt{ } \mathrm{p}$ (1-p)/ n where p stands for Prevalence. The software automatically provided the Confidence Interval (CI) according to the calculated SE, if the CI is provided in a study; it was introduced accordingly. The heterogeneity of each meta-analyses was assessed. The random effects were favored over the fixed effects model in all meta-analysis established as differences between studies are predicted to be possible due to the diversity of the study populations. Sensitivity analysis was also approached to determine the effect of studies conducted on populations which are proposed to behave in indifferent manners or proposed to be more aware of the overall pooled prevalence. Moreover, subgroup analysis was also conducted -whenever suitable to determine awareness level in a specific country or population. A question to participate in the meta-analysis must be included in at least three studies, and questions with similar outcomes were proposed to be the same. 


\section{Results}

\subsection{Characteristics of the Included Studies}

A total of 11,038 published articles were identified from the search strategy. Also, we involved the hand search of reference lists of included original research articles and reviews. Among these articles, 163 articles met our inclusion criteria and passed the quality assessment procedure. Twenty-nine articles have reported the prevalence of microbiological infections, while 34 articles have determined the vaccination status among African HCWs. Furthermore, 108 included studies have assessed the awareness and attitude toward different microbial infections. The oldest studies were published in 2010, while the most recent ones were published in 2020. Figure 1 shows the PRISMA flow diagram. The included articles in this meta-analysis and the assessment of their quality are illustrated in S1 Table and S2 Table, respectively. Three hundred forty-seven questions were summarized, among which 96 questions were analyzed and synthesized. Publication bias assessment indicated no major asymmetry.

\subsection{Microbiological Infections Among African HCWs}

Twenty-nine included studies have assessed the prevalence of different types of microbial infections among 12,342 African HCWs in a total of 12 countries. Eight studies were conducted in Ethiopia $(15)(16)(17)(18)(19)(20)(21)(22)$, four in Cameroon $(23)(24)(25)(26)$, three in each of South Africa (27)(28)(29) and Tanzania (30)(31)(32), two in each of Kenya (33)(34), Sierra Leone (35)(36) and Ghana (37)(38); one in each of Egypt (39), Nigeria (40), Mozambique (41), Sudan (42) and Madagascar (43). The conduction of the studies ranged from 2009 to 2018. Twenty variables were collected 
from the participants, and 12 of them were analyzed and synthesized. Variables analyzed, their corresponding articles' data, the pooled prevalence and the confidence intervals are illustrated in Table 1.

\subsubsection{HBV and HCV}

Fourteen studies have investigated the prevalence of HBV, among which three studies have investigated the prevalence of HCV too (44)(17)(39). These studies were conducted in Cameron (23)(24)(25), Sierra Leone (36)(35), Tanzania (44)(31)Ethiopia (16)(17), Kenya (33), Egypt (39), Nigeria (40), Ghana (37) and South Africa (27). The oldest among included studies was conducted in 2012, while the newest was conducted in 2018. The prevalence of HBV (HBsAg) was tested for 6,599 African HCWs;6.00\% [95\% Cl; 3.66, 8.33] were positive. While the prevalence of HCV (anti-HCV) was investigated for 1,489 African HCWs; 0.81\% [95\% Cl; -4.27, 5.89] were positive, see Table 1, Figure 2 and Figure 3.

\subsubsection{Other Microbial Infections}

Three articles have studied HIV infection, were conducted in Ethiopia (18), Cameroon (26) and Tanzania (32) in which two studies have investigated the occupational exposure to HIV infection as well (18)(32). In addition, two studies have assessed HIV and TB coinfection which were conducted in South Africa (28) and Kenya (34). The two studies, and another study conducted in Mozambique (41), have also investigated latent tuberculosis infection prevalence (LTB). The prevalence of HIV was assessed for 1,705 African HCWs; 9.06\% [95\% Cl; -6.03, 24.16] were positive. While the prevalence of 
occupational Latent TB (LTB) by tuberculin skin test (TST) was 59.82\% [95\% Cl; 36.90, 82.75] among 1,436 participants, and the heterogeneity was high $\left(\mathrm{I}^{2}=98 \%\right)$.

\subsubsection{Occupational Exposure}

History of occupational exposure to blood-borne viruses (HBV, HCV and HIV) was assessed for 1,017 African HCWs by four studies conducted in Ethiopia (15)(17)(18) and Tanzania (32). A 81.20\% [95\% Cl; 69.57, 92.82] were occupationally exposed to bloodborne viruses. Furthermore, three studies have investigated the prevalence of $S$. aureus (nasal colonization) among 1,093 African HCWs;13.36\% [95\% Cl; 7.87, 18.85] were positive. These studies were conducted in Sudan (42), Ghana (38), Madagascar (43).

Seven studies have assessed the occupational exposure to needle stick injuries, while four have studied the exposure to sharp injuries in general. These studies were conducted in Ethiopia (18)(20)(21)(19)(22), Sierra Leone (36), Tanzania (32)(31), Egypt (39) and South Africa (29). History of exposure to needle stick injuries was investigated for 1,830 participants; $26.81 \%$ [95\% Cl; 14.58, 39.05] were identified exposed, while the history of exposure to sharp injuries was assessed for 1,307 participants; $27.83 \%$ [14.29, 41.37] were found exposed.

Furthermore, a history of exposure to blood or body fluids was assessed by five studies conducted in Ethiopia (15)(21), Tanzania (31)(32) and Guinea (45). Eight hundred and forty-seven African HCWs were asked about their exposure to a splash of blood or body fluid on intact skin; 68.57\% [95\% Cl; 38.66, 98.49] answered yes. Also, a history of the splash of blood or body fluids to the eye or mouth was investigated by 1,830 participants; $26.81 \%$ [95\% Cl; 14.58, 39.05] answered yes (Table 1). 


\subsection{Vaccination Status of African HCWs}

Thirty-four included studies have assessed the vaccination of 12,785 African HCWs regarding HBV, HIV, influenza, and TB infection in 11 countries. Six studies were conducted in Nigeria (40)(46)(47)(48)(49)(50), five studies in each of Tanzania $(30)(51)(52)(44)(31)$, Ethiopia $(15)(53)(20)(54)(55)$, and Cameroon $(56)(23)(24)(57)(58)$, two studies in each of Ghana (59)(37), Libya (60)(61), Sierra Leone (62)(36), Kenya (33)(63) and South Africa (64)(27), one in each of Senegal (65), Rwanda (66) and Zambia (67). The conduction of the studies ranged from 2009 to 2018 (Table 2). Eight questions were asked to African HCWs related to their vaccination status; however, six questions were analyzed and synthesized. The question "Are you fully vaccinated against HBV?" was answered by 12,036 African HCWs in Tanzania, Nigeria, Ethiopia, Cameroon, Kenya, Ghana, Zambia, South Africa and Libya; 43.22\% [95\% Cl; 31.22, 55.21] answered yes. The question "Are you unvaccinated against HBV?" were asked to 7,123 HCWs from Tanzania, Nigeria, Ethiopia, Cameroon and Libya; 58.42\% [95\% Cl; 42.27, 74.57] answered yes. Questions asked, their corresponding articles' data, the pooled prevalence, value of Heterogeneity, $\mathrm{p}$-value and the confidence intervals are shown in Table 3. Heterogeneity was high in all questions $\left(\mathrm{I}^{2}\right.$ more than $\left.89 \%\right)$, except for the question "Did you take two doses of hepatitis B vaccine?" where $\mathrm{I}^{2}=40 \%$.

\subsection{Awareness and Attitude among African HCWs}

\subsubsection{Awareness and attitude toward HBV}

Twenty-nine included studies have assessed the awareness and attitude toward HBV among 5,761 African HCWs. These studies were conducted in Tanzania 
$(44)(31)(51)(52)$, Nigeria $(48)(49)(40)(46)(68)$, Ethiopia $(15)(53)(69)(70)(71)(17)$, Ghana (72)(59), Kenya (33)(63), Côte d'Ivoire (73), Sierra Leone (35)(36), Cameroon (24)(57)(58), Egypt (74), Senegal (65)(75), and Sudan (76). The oldest article among the included studies was conducted in 2010, while the newest was conducted in 2017. Seventy-eight questions related to $\mathrm{HBV}$ awareness and attitude were asked to the participants, and 27 of them were analyzed and synthesized. The question "should HBV vaccine be compulsory for all health care workers?" was answered by 1,375Africans HCWs in four countries; 89.57\% [95\% Cl; 83.13, 96.01] answered yes. While the question "Is your reason for being unvaccinated, unavailability of the vaccine at your working place?" was answered by 1,240 Africans HCWs in five countries; 47.67\% [95\% Cl; 30.57, 64.77] answered yes. Questions analyzed, their corresponding articles' data, the pooled prevalence and the confidence intervals are depicted in Table 3.

\subsubsection{Awareness and Attitude toward HIV}

Nineteen included studies have investigated the awareness of African HCWs regarding HIV; six studies were conducted in Tanzania (77)(78)(32)(79)(80)(81), five in Nigeria $(82)(83)(84)(85)(86)$, four in Ethiopia $(18)(71)(55)(22)$, and one in each of Cameroon (87), Rwanda (66), South Africa (88) and Kenya (89). The oldest among them was conducted in 2010, while the newest was conducted in 2018. Thirty questions were asked to the participants related to their knowledge about HIV, transmission routes, its clinical symptoms, HIV investigation tests, prevention attitude, HIV-post exposure prophylaxis (PEP) and their source of information. Among them, 11 questions were analyzed and synthesized (Table 4). The question "Do you consider yourself to be at risk for HIV acquisition at your workplace?" was asked for 1,176; 75.03\% [95\% Cl; 58.13, 91.93] 
answered yes. In addition, the question "Ever Heard about HIV Post Exposure Prophylaxis (PEP)?" was asked for 1,013 African HCWs from Nigeria, Cameroon, Tanzania, and Ethiopia; 90.62\% [95\% Cl; 84.55, 96.69] answered yes. While the question "Ever had training on PEP?" was asked for 494 African HCWs from Cameroon, Ethiopia, and Tanzania; 50.45\% [95\% Cl; 24.09, 76.81] answered yes. Questions asked, their corresponding study's countries, the pooled prevalence and the confidence intervals are depicted in Table 4.

\subsubsection{Awareness and attitude toward TB}

Thirteen published articles have studied the awareness and attitude of TB among 2,765 in a total of five countries, four in Ethiopia $(90)(91)(54)(92)$, three in both Nigeria (93)(94)(95) and Lesotho (96)(97)(98), two in South Africa (88)(99) and one in Uganda (100). The conduction of the studies ranged from 2010 to 2015. Sixty-three questions were asked to the participants related to the administrative, environmental and personal tuberculosis control measures, knowledge toward tuberculosis transmission, predisposing factors, prevention, diagnosis and treatment, and attitudes towards preventive methods of nosocomial tuberculosis. However, 14 questions were analyzed and synthesized. The question "Doses HIV consider a predisposition to contracting TB?" were answered by 1,547 participants; $77.11 \%$ [95\% Cl; 68.48, 85.74] answered yes. Also, the question "Do you agree that surgical masks do not protect the wearer against TB infection?" was answered by 1,316 participants; $35.28[95 \% \mathrm{Cl} ; 30.90,39.65]$ answered yes. Heterogeneity was high in all questions ( $\mathrm{I}^{2}$ more than $\left.80 \%\right)$. Except for the question "Do you agree that surgical masks do not protect the wearer against TB infection?" where $\mathrm{I}^{2}=$ 
40\%. Questions asked, their corresponding articles' data, the pooled prevalence, value of Heterogeneity, P-value and the confidence intervals are shown in Table 5.

\subsubsection{Awareness \& Attitude toward Antibiotics}

Eight studies have assessed the awareness toward antibiotics among 1,761 African HCWs in Ethiopia (101), Gambia (102), Ghanaian (103), Egypt (104), Nigeria (105), Uganda (106) and Lesotho (96). In addition, Bulabulaet al. performed an online questionnaire (SurveyMonkey) in both French and English, which was circulated via the Infection Control Africa Network ( ICAN )/ BSAC on the education and management of antimicrobials amongst nurses from different African countries Democratic Republic of Congo (DRC), Egypt, Kenya, Liberia, Namibia, Nigeria, Rwanda, Sierra Leone, South Africa, Swaziland, Senegal and Zimbabwe (107). The conduction of the studies ranged from 2010 to 2016. Fifteen antibiotics questions were asked, in which three are analyzed and synthesized; see Table 6 for more illustration.

According to our analysis, the most crucial perceived factors that were determined by African HCWs, contributing to the development of antimicrobial resistance were: widespread or overuse of antibiotics $77.75 \%[95 \% \mathrm{Cl} ; 71.99,83.52]$ and patients' poor adherence to prescribed antibiotics $47.18 \%$ [95\% Cl; -2.80, 97.16]. Furthermore, the most important local factor identified among respondents for the spread of AMR was selfantibiotic prescription $42.00 \%[18.79,65.20]$. Questions asked, their corresponding articles' data, the pooled prevalence, value of Heterogeneity, P-value and the confidence intervals are shown in Table 6.

\subsubsection{Awareness \& Attitude toward Infection Control}


Twenty-one included studies have investigated the awareness, attitude and practice of infection control measures among African HCWs who were from Nigeria $(108)(109)(110)(111)(48)(112)(113), \quad$ Ethiopia $\quad(22)(114)(71)(115)(20)(54)(71)(17)$, Uganda (116)(117), Egypt (74), Kenya (118), Sierra Leone (119) and Benin (120). The oldest study was conducted in 2010, while the newest was conducted in 2018. Sixty-eight questions were asked to the participants regarding knowledge, attitude, and practice of infection control; however, 18 were analyzed and synthesized. The question "Does the infection prevention and control (IPC) guideline available in your workplace?" was asked to $1,582 \mathrm{HCW}$ from Ethiopia and Sierra Leone; 50.95\% [95\% Cl; 40.22, 61.67] answered yes. Regarding the prevention measures against needle stick Injuries, the question "Do you practice recapping syringes?" was asked to $742 \mathrm{HCWs}$; $43.41 \%$ [95\% $\mathrm{Cl} ; 23.78,63.04]$ answered yes. While, the question "Do you use alcohol swab after needle stick?" was answered by $666 \mathrm{HCWs}$, and $63.80 \%$ [95\% Cl; 47.85, 79.74] of them answered yes. In addition, the question "Do you know that the safety box should be closed/sealed when three quarters filled?" was asked to 1,170 HCWs from Ethiopia; $65.80 \%[95 \% \mathrm{Cl} ; 44.09,87.51]$ answered yes. Questions asked, their corresponding articles' data, the pooled prevalence, value of Heterogeneity, P-value and the confidence intervals are depicted in Table 7.

\subsubsection{Miscellaneous studies}

Eighteen studies have assessed awareness and attitude of African HCWs toward different aspects, including Ebola virus, Influenza virus, Zika virus, zoonotic diseases (rabies, anthrax, dengue, and chikungunya), Buruli ulcer disease, human papillomavirus (HPV), atopic dermatitis, Lassa fever, aflatoxin contamination in groundnut and its ingestion risk, 
compassion practice towards HIV patients (nursing practice), and Provider-initiated testing and counselling (PITC) for HIV. These articles were from Nigeria (121)(122)(109)(123), Uganda (124)(125), Cote d'Ivoire (126), Cameroon (127), Ethiopia (128), Sierra Leone (62), Tanzania (129)(81) and South Africa (64)(130). Thirty-eight questions were summarized, among which only one question was analyzed and synthesized. The question was, "do you agree that Influenza is more serious than a “common cold", and patients to be hospitalized or die from influenza?". It was asked for 1,096 African HCWs from Cote d' Ivoire(126), Sierra Leone (62) and South Africa (64), however, $90.50 \%[95 \% \mathrm{Cl} ; 82.85,98.15]$ answered yes $\left(\mathrm{Tau}^{2}=42.82 ; \mathrm{Chi}^{2}=34.47, \mathrm{df}=\right.$ $\left.2(\mathrm{P}<0.00001) ; \mathrm{I}^{2}=94 \%\right)$. 


\section{Discussion}

This systematic review has attempted, for the first time, to collate all research conducted in Africa reporting any aspect of microbiological assessment among HCWs. The results presented analyzed data about the prevalence of microbial infections, vaccination status and awareness and attitude toward microbial infections among African HCWs to plan and implement adequate preventive measures, optimize practitioners' knowledge and inform researchers what is done in this area while simultaneously identifying potential gaps in knowledge on this area of study.

The current study has assessed the prevalence of different types and causes of microbial infections among 12,342 African HCWs in 12 countries. The prevalence of HBV (HBsAg), HCV (anti-HCV) and HIV were $6.00 \%, 0.81 \%$ and $9.06 \%$, respectively. The risk of $\mathrm{HBV}, \mathrm{HCV}$ or $\mathrm{HIV}$ infecting $\mathrm{HCW}$ is higher than general populations because they are frequently exposed to potentially infectious biological materials. However, HBV and HCV epidemiology exhibits considerable geographical differences, and accordingly, the prevalence of HBV and HCV among HCWs varies as well (for a review, see (131)). Regarding HIV epidemiology, the Sub-Saharan African belt bears the brunt of HIV infection (132)(133)(134), and HCWs are at high risk of HIV infection from both occupational exposure and sexual transmission (135). Moreover, in this study, the evidence base shows a high burden (59.82\%) of occupational Latent TB (LTB) among African HCWs. However, high LTB incidence was also reported in India among HCWs (136)(137). Although HCWs potentially expose to a different type of occupational hazard, many HCWs lack awareness about prevention and control. In African and developing countries, prevention policies are unclear, inaccessible, or attitude problem 
medRxiv preprint doi: https://doi.org/10.1101/2021.10.14.21264931; this version posted October 16, 2021. The copyright holder for this preprint

that made HCWs suffer (138). In this study, 81.20\% of African HCWs were occupationally exposed to blood-borne viruses (HBV, HCV, and HIV). The global burden of blood-borne diseases from occupational exposure, based on the world health organization estimation, is around $40 \%$ of the hepatitis B and C infections and $2.5 \%$ of the HIV infection (139)(140)(141). In addition, occupational exposure to sharp and needlestick injuries represents a global problem. In the USA, According to the CDC report, the annual number of injuries among the hospital staff is 385,000 (142). While in Europe, over 1 million needle-stick injuries are suffered by healthcare workers each year (143). Moreover, the reported incidence rates of needlestick injuries annually were 100/1000 healthcare workers in Finland and 2.2/100 full-time equivalent physicians and 7.0/100 nurses in France (144)(145). In this study, the pooled prevalence of historical exposure to needle stick injuries and sharp injuries were $26.81 \%$ and $27.83 \%$ among 1,830 and 1,307 African HCWs, respectively.

Being a healthcare worker put you endanger of acquiring a vaccine-preventable disease (VPD) (146). As for this, vaccination was a very effective and safe way to prevent VPD (147). According to $\mathrm{WHO}$, there are vaccines available to protect against at least 20 diseases (147), amongst which HBV vaccine, which is considered the most important one for HCWs providing the fact that hepatitis B infection is four times greater than that of the general adult population (148). Despite this, in our study, we found that $58.42 \%(\mathrm{n}=$ 7,123) of HCWs in Africa were unvaccinated in comparison to $46.1 \%$ in India (149), $24 \%$ in Turkey (150) and $19.3 \%$ in Brazil (148). In contrast, vaccination coverage was $43.22 \%(n=12,036)$ which is lower when compared to $77 \%$ in each of Italy, Australia and New Zealand (151), China 60\% (152), Pakistan 73.42\% (153), India 56\% (154), Iran 
48.1\% (155) and USA 63.4\%, and is the highest in French healthcare students $(91.8 \%)$ probably for mandatory vaccination (156)(157). Therefore, because of excellent vaccination coverage in France and compulsory vaccination and given that high hepatitis B infection rate among African HCWs offset by low vaccination coverage, we strongly recommend $\mathrm{HBV}$ vaccine to be an obligatory prerequisite for work. This policy will greatly value HCWs regarding their health state and, therefore their service.

Measuring awareness toward blood born infections in HCWs is vital since their a high risk of contracting them (158) as the incidence of needle stick injuries are high in their work field (147). Opening with HIV as it demonstrated the highest prevalence among African HCWs, our study found that most of them consider themselves at risk for HIV acquisition at their workplace by $75.03 \%$, which is lower when compared to South India $(100 \%)(158)$ and Serbia (89\%) (3), but higher than the $62 \%$ recorded among HCWs in Israel (4). The majority of HCWs have Heard about HIV Post Exposure Prophylaxis (PEP) (90.62\%); similarly, high rates were identified in South India (158) and so much less in Serbia (3). Surprisingly only $50.45 \%$ had training on PEP in contrast to $68.5 \%$ in South India (158). Nevertheless, a much lower rate was reported in Serbia (3). Regarding attitude towards $\mathrm{HBV}$ and its vaccination, it was interestingly high the percentage of HCWs stating that vaccines should be compulsory $(89.57 \%)$ in line with a study done in Iraq (161). Unfortunately, $47.67 \%$ of African health care workers declared that the reason for not being vaccinated was the unavailability of the vaccine, which was also mentioned as one of the top reasons in several studies conducted in China (152), Iran (155) and Pakistan (153)(162). Considering this high percentage, the significance of providing the HBV vaccine at work would help in improving the vaccination status among HCWs. 
Furthermore, in light of the high burden of TB among African HCWs, knowledge and implementation of TB control measures by HCWs and their compliance and willingness are required to manage healthcare-associated $\mathrm{TB}$ effectively. The WHO and CDC proposed numerous comprehensive IPC guidelines which have been designed for healthcare facilities, inclusive of low-resourced settings (163)(164)(165). IPC measures have been proposed at three levels: administrative, environmental and personal respiratory protection. The managerial control measures represent the priority, while the other two are dependent on administrative control measures for their effectiveness (166). In this study, $37.77 \%$ screened suspicious TB patients in waiting areas, and $47.21 \%$ prioritized TB suspects for prompt service. These poor practices of administrative IPC measures are many pitfalls since these should be implemented at first contact with an infectious patient at a health facility. Delays in screening, diagnosis and treatment of TB would increase the risk of healthcare-associated TB. Environmental IPC measures, which are second-line IPC practices, are dependent on the use of ventilation and irradiation and infrastructural design of the facility; however, more straightforward effective methods have been suggested based on adequate ventilation through the opening of windows (164). in this study, $57.07 \%$ of respondents isolate the patients or use of separate TB ward, and $75.40 \%$ of respondents open windows for ventilation and sunlight. In addition, the findings regarding PPE were of concern. We found that $49.08 \%$ of respondents use a mask when approaching TB suspected patients, which agrees with Biscotto et al. finding that HCWs infrequently used masks $(39.5 \%)$ when performing procedures or attending patients with a high risk of healthcare-associated TB (167). 
Antimicrobial resistance (AMR) represents a serious growing challenge, especially in low-income countries such as African countries, because of irrational uses of antimicrobials, lack of clinical microbiology laboratories for antimicrobial susceptibility testing, over-the-counter availability of antibiotics high prevalence of infection (168). However, containment of AMR demands changes in HCWs' behavior towards the magnitude of AMR problem, prevention the transmission of resistant microbes, prescribing antimicrobials wisely and promoting awareness on AMR for patients and communities (101). Therefore, information on HCWs' knowledge and awareness of AMR will permit more effective interventions on AMR containment. In this study, the most crucial perceived factors that were determined by African HCWs, contributing to AMR development were widespread or overuse of antibiotics $(77.75 \%$ by respondents) and patients' poor adherence to prescribed antibiotics (47.18\%). Likewise, previous studies conducted in Scotland, France and Spain found these factors among the leading causes of AMR development (169)(170). In addition, this study revealed that the most important local factor for the development and spread of AMR was self-antibiotic prescription (42\% by respondents) which is similar to previous studies (171)(168).

Adherence to IPC guidelines is a key to protect HCWs and prevent transmission of infections, and it becomes even more important when infectious diseases become widespread, such as during the COVID-19 pandemic. In this review, we found that the availability of IPC guidelines in African HCWs' workplaces was 50.95\% which is consistent with a study conducted in Italy (172). Strategies in IPC guidelines include stricter cleaning routines, the separation of patients with respiratory infections from others, and personal protective equipment (PPE) such as masks, gloves and gowns. 
However, practicing these strategies can be difficult and time-consuming; therefore, authorities and healthcare facilities need to consider the best way to support healthcare workers to implement them. The findings presented in this study regarding the implementation of PPE among African HCWs were $35.86 \%$ wash their hands with soap before patient care; $71.62 \%$ wash their hands with soap after patient care/contact with fluid; $69.56 \%$ wash their hands without soap before and after patient care; $61.28 \%$ wear fresh gloves before examining new patients; $36.10 \%$ are routinely masked before entering the ICU; $43.81 \%$ are you routinely gowned before entering the ICU, and $41.91 \%$ are routinely worn goggle before entering the ICU (Table 7). These findings are relatively lower compared with results of other similar previous work (173).

\section{Conclusion}

Healthcare workers are god's safeguard of life, especially in continents suffering poverty, conflicts, illiteracy, and fragile infrastructures. The current study determined many weaknesses to be addressed for the sake of improving health in Africa. Therefore, the current pooled data are critically significant to be used in planning governmental or NGOs strategies. 


\section{Ethical approval}

Not applicable

\section{Consent for publication}

Not applicable

\section{Data Availability Statement}

All relevant data are available within the manuscript and as supplementary materials.

\section{Funding}

The authors received no specific funding for this work.

\section{Conflict of interest}

The authors have declared that no competing interests exist.

\section{Authors' contributions}

Conceptualization: Marwan M. Badawi

Data curation: Abeer B. Idris, Alaa B. Idris

Data analysis: Elfatih A. Hasabo

Supervision: Marwan M. Badawi

Writing - original draft: Abeer B. Idris, Alaa B. Idris, Marwan M. Badawi, Elfatih A. Hasabo 
Writing - review \& editing: Nazar Beirag, Abeer B. Idris, Alaa B. Idris, Marwan M.

Badawi

\section{Supplementary files}

S1 Table. Characteristics of the included studies.

S1 Table. Assessment of the quality of the included studies.

\section{References}

1. Vallés J, Calbo E, Anoro E, Fontanals D, Xercavins M, Espejo E, et al. Bloodstream infections in adults: Importance of healthcare-associated infections. J Infect. 2008;56(1):27-34. doi: 10.1016/j.jinf.2007.10.001.

2. UNAIDS. Fact sheet - Latest statistics on the status of the AIDS epidemic. 2018. Available at: http://www.unaids.org/en/resources/fact-sheet.

3. Micek ST, Kollef KE, Reichley RM, Roubinian N, Kollef MH. Health careassociated pneumonia and community-acquired pneumonia: a single-center experience. Antimicrob Agents Chemother. 2007;51(10):3568-73. doi: 10.1128/AAC.00851-07.

4. Park SC, Kang YA, Park BH, Kim EY, Park MS, Kim YS, et al. Poor prediction of potentially drug-resistant pathogens using current criteria of health care-associated pneumonia. Respir Med. 2012;106(9):1311-9. doi: 10.1016/j.rmed.2012.04.003. 
5. UNAIDS. Global Report: UNAIDS Report on the Global AIDS Epidemic 2010. 2010. http://data.unaids.org/pub/Report/2009/JC1700_Epi_Update_2009_en.pdf (accessed 9 Jan 2019).

6. World Health Organization. Global tuberculosis report 2016 Available at: http://www.who.int/tb/publications/global_report/en/. Accessed 6 Febuary 2019.

7. Benito N, Miro JM, de Lazzari E, Cabell CH, del Rio A, Altclas J, et al. Health care-associated native valve endocarditis: importance of Non-nosocomial acquisition. Ann Intern Med. 2009;150(9):586-94. doi: 10.7326/0003-4819-150-9200905050-00004.

8. Aguilar-Duran S, Horcajada JP, Sorlí L, Montero M, Salvadó M, Grau S, et al. Community-onset healthcare-related urinary tract infections: comparison with community and hospital-acquired urinary tract infections. J Infect. 2012;64(5):478-83. doi: 10.1016/j.

9. World Health Organization. Hepatitis B. Fact sheet No. 204. WHO; 2018. Available at: http://www.who.int/mediacentre/factsheets/fs204/en/ (Accessed Jan 2019).

10. No TitleLaia Bruni, Mireia Diaz, Xavier Castellsague', Elena Ferrer, F. Xavier Bosch and S de S. Cervical Human Papillomavirus Prevalence in 5 Continents: Meta-Analysis of 1 Million Women with Normal Cytological Finding. J Infect Dis. 2010;202:1789-99.

11. Moher D, Liberati A, Tetzlaff J, Altman DG, Group P. Preferred reporting items 
for systematic reviews and meta-analyses: the PRISMA statement. PLoS Med [Internet]. 2009/07/21. 2009 Jul 21;6(7):e1000097-e1000097. Available from: https://pubmed.ncbi.nlm.nih.gov/19621072

12. Badawi MM, SalahEldin MA, Idris AB, Hasabo EA, Osman ZH, Osman WM. Knowledge gaps of STIs in Africa; Systematic review. PLoS One [Internet]. 2019 Sep 12;14(9):e0213224-e0213224. Available from: https://pubmed.ncbi.nlm.nih.gov/31513584

13. Badawi MM, Atif MS, Mustafa YY. Systematic review and meta-analysis of HIV, HBV and HCV infection prevalence in Sudan. Virol J [Internet]. 2018 Sep 25;15(1):148. Available from: https://pubmed.ncbi.nlm.nih.gov/30253805

14. Duval S, Tweedie R. Trim and Fill: A Simple Funnel-Plot-Based Method of Testing and Adjusting for Publication Bias in Meta-Analysis. Biometrics [Internet]. 2000 Jun 1;56(2):455-63. Available from: https://doi.org/10.1111/j.0006-341X.2000.00455.x

15. Abeje G, Azage M. Hepatitis B vaccine knowledge and vaccination status among health care workers of Bahir Dar City Administration, Northwest Ethiopia: a cross sectional study. BMC Infect Dis [Internet]. 2015 Dec 31;15(1):30. Available from: http://bmcinfectdis.biomedcentral.com/articles/10.1186/s12879-015-0756-8

16. Yizengaw E, Getahun T, Geta M, Mulu W, Ashagrie M, Hailu D, et al. Seroprevalence of hepatitis B virus infection and associated factors among health care workers and medical waste handlers in primary hospitals of North-west Ethiopia. BMC Res Notes. 2018 Jul;11(1):437. 
17. Hebo HJ, Gemeda DH, Abdusemed KA. Hepatitis B and C Viral Infection: Prevalence, Knowledge, Attitude, Practice, and Occupational Exposure among Healthcare Workers of Jimma University Medical Center, Southwest Ethiopia. Sci World J. 2019;2019:11.

18. Aynalem Tesfay F, Dejenie Habtewold T. Assessment of Prevalence and Determinants of Occupational Exposure to HIV Infection among Healthcare Workers in Selected Health Institutions in Debre Berhan Town, North Shoa Zone, Amhara Region, Ethiopia, 2014. AIDS Res Treat. 2014;2014:731848.

19. Reda AA, Fisseha S, Mengistie B, Vandeweerd J-M. Standard Precautions: Occupational Exposure and Behavior of Health Care Workers in Ethiopia. Tripathy S, editor. PLoS One [Internet]. 2010 Dec 23;5(12):e14420. Available from: https://dx.plos.org/10.1371/journal.pone.0014420

20. Sharew NT, Mulu GB, Habtewold TD, Gizachew KD. Occupational exposure to sharps injury among healthcare providers in Ethiopia regional hospitals. Ann Occup Environ Med [Internet]. 2017 Dec 23;29(1):7. Available from: http://aoemj.biomedcentral.com/articles/10.1186/s40557-017-0163-2

21. Sahiledengle B, Gebresilassie A, Getahun T, Hiko D. Infection prevention practices and associated factors among healthcare workers in governmental healthcare facilities in Addis Ababa. Ethiop J Health Sci [Internet]. 2018 Mar $22 ; 28(2): 177$. Available from: https://www.ajol.info/index.php/ejhs/article/view/168651

22. Sharew TDYGB, Wondwossen A. Knowledge, attitude, and practice of healthcare 
professionals regarding infection prevention at Gondar University referral hospital, northwest Ethiopia: a cross-sectional study. BMC Res Notes. 2019;12:563.

23. Bilounga Ndongo C, Eteki L, Siedner M, Mbaye R, Chen J, Ntone R, et al. Prevalence and vaccination coverage of Hepatitis B among healthcare workers in Cameroon: A national seroprevalence survey. J Viral Hepat. 2018;25(12):1582-7.

24. Tatsilong HOP, Noubiap JJN, Nansseu JRN, Aminde LN, Bigna JJR, Ndze VN, et al. Hepatitis B infection awareness, vaccine perceptions and uptake, and serological profile of a group of health care workers in Yaoundé, Cameroon. BMC Public Health [Internet]. 2016 Dec 3 [cited 2018 Dec 3];16(1):706. Available from: $\quad$ http://bmcpublichealth.biomedcentral.com/articles/10.1186/s12889-016$3388-\mathrm{Z}$

25. W EA, Tume C, Njouom R, Ayong L, Fondoh V, Jules-Roger K. Knowledge, attitude and prevalence of hepatitis B virus among healthcare workers: a crosssectional, hospitalbased study in Bamenda Health District, NWR, Cameroon. BMJ Open. 2020;10:e031075.

26. Domkam IK, Sonela N, Kamgaing N, Takam PS, Gwom L-C, Betilene TMA, et al. Prevalence and risk factors to HIV-infection amongst health care workers within public and private health facilities in Cameroon. Pan Afr Med J. 2018;29:158.

27. Sondlane TH, Mawela L, Razwiedani LL, Selabe SG, Lebelo RL, Rakgole JN, et al. High prevalence of active and occult hepatitis B virus infections in healthcare workers from two provinces of South Africa. Vaccine. 2016 Jul;34(33):3835-9. 
28. Adams S, Ehrlich R, Baatjies R, van Zyl-Smit RN, Said-Hartley Q, Dawson R, et al. Incidence of occupational latent tuberculosis infection in South African healthcare workers. Eur Respir J [Internet]. 2015 May;45(5):1364-73. Available from: http://erj.ersjournals.com/lookup/doi/10.1183/09031936.00138414

29. Mbah CCE, Elabor ZB, Omole OB. Occupational exposure to blood and body fluids among primary healthcare workers in Johannesburg health district: High rate of underreporting. S Afr Fam Pr. 2020;62(1):a5027.

30. Mueller. A, L. Stoetter, S. Kalluvya, A. Stich, C. Majinge BW and CK. Prevalence of hepatitis B virus infection among health care workers in a tertiary hospital in Tanzania. BMC Infect Dis. 2015 Oct 23;15(386):1-9.

31. Shao ER, Mboya IB, Gunda DW, Ruhangisa FG, Temu EM, Nkwama ML, et al. Seroprevalence of hepatitis B virus infection and associated factors among healthcare workers in northern Tanzania. BMC Infect Dis [Internet]. 2018 Dec $21 ; 18(1): 474$. Available from: https://bmcinfectdis.biomedcentral.com/articles/10.1186/s12879-018-3376-2

32. Mashoto KO, Mubyazi GM, Mohamed H, Malebo HM. Self-reported occupational exposure to HIV and factors influencing its management practice: a study of healthcare workers in Tumbi and Dodoma Hospitals, Tanzania. BMC Health Serv Res [Internet]. 2013 Dec 17;13(1):276. Available from:

33. Kisangau EN, Awour A, Juma B, Odhiambo D, Muasya T, Kiio SN, et al. Prevalence of hepatitis B virus infection and uptake of hepatitis B vaccine among healthcare workers, Makueni County, Kenya 2017. J Public Health (Bangkok) 
[Internet]. 2018 Oct 23 [cited 2018 Dec 19];1-7. Available from: https://academic.oup.com/jpubhealth/advancearticle/doi/10.1093/pubmed/fdy186/5142651

34. Agaya J, Nnadi CD, Odhiambo J, Obonyo C, Obiero V, Lipke V, et al. Tuberculosis and latent tuberculosis infection among healthcare workers in Kisumu, Kenya. Trop Med Int Heal [Internet]. 2015 Dec;20(12):1797-804. Available from: http://doi.wiley.com/10.1111/tmi.12601

35. Massaquoi TA, Burke RM, Yang G, Lakoh S, Sevalie S, Li B, et al. Cross sectional study of chronic hepatitis B prevalence among healthcare workers in an urban setting, Sierra Leone. Blackard J, editor. PLoS One [Internet]. 2018 Aug 10;13(8):e0201820. Available from: https://dx.plos.org/10.1371/journal.pone.0201820

36. Qin Y-L, Li B, Zhou Y-S, Zhang X, Li L, Song B, et al. Prevalence and associated knowledge of hepatitis B infection among healthcare workers in Freetown, Sierra Leone. BMC Infect Dis [Internet]. 2018 Dec 9;18(1):315. Available from: https://bmcinfectdis.biomedcentral.com/articles/10.1186/s12879-018-3235-1

37. Obiri-YeboahID D, Awuku YA, Adjei G, Cudjoe O, Anna, Benjamin H, et al. Post Hepatitis B vaccination sero-conversion among health care workers in the Cape Coast Metropolis of Ghana. PLoS One. 2019;14(6):e0219148.

38. Egyir B, Guardabassi L, Nielsen SS, Larsen J, Addo KK, Newman MJ, et al. Prevalence of nasal carriage and diversity of Staphylococcus aureus among inpatients and hospital staff at Korle Bu Teaching Hospital, Ghana. J Glob 
Antimicrob Resist. 2013 Dec;1(4):189-93.

39. Abdelwahab SF, Hashem M, Galal I, Sobhy M, Abdel-Ghaffar TS, Galal G, et al. Incidence of hepatitis $\mathrm{C}$ virus infection among Egyptian healthcare workers at high risk of infection. J Clin Virol [Internet]. 2013 May;57(1):24-8. Available from: https://linkinghub.elsevier.com/retrieve/pii/S1386653213000103

40. Abiola A-HO, Agunbiade AB, Badmos KB, Lesi AO, Lawal AO, Alli QO. Prevalence of $\mathrm{HBsAg}$, knowledge, and vaccination practice against viral hepatitis B infection among doctors and nurses in a secondary health care facility in Lagos state, South-western Nigeria. Pan Afr Med J [Internet]. 2016;23:160. Available from: http://www.panafrican-med-journal.com/content/article/23/160/full/

41. Belo C, Naidoo S. Prevalence and risk factors for latent tuberculosis infection among healthcare workers in Nampula Central Hospital, Mozambique. BMC Infect Dis. 2017 Jun;17(1):408.

42. Eltayib Hassan Ahmed-Abakur, Ibtehaj Saleh, Mohamed Ahmed I. Holi SKK. Bacteriological Assessment of Hand Hygiene and Antimicrobial Susceptibility Patterns of Isolated Nosocomial Species of Nurses at Khartoum Teaching Hospital. Clin Med Diagnostics. 2013;3(3):70-4.

43. Hogan B, Rakotozandrindrainy R, Al-Emran H, Dekker D, Hahn A, Jaeger A, et al. Prevalence of nasal colonisation by methicillin-sensitive and methicillinresistant Staphylococcus aureus among healthcare workers and students in Madagascar. BMC Infect Dis [Internet]. 2016 Dec 15;16(1):420. Available from: http://bmcinfectdis.biomedcentral.com/articles/10.1186/s12879-016-1733-6 
44. Mueller A, Stoetter L, Kalluvya S, Stich A, Majinge C, Weissbrich B, et al. Prevalence of hepatitis B virus infection among health care workers in a tertiary hospital in Tanzania. BMC Infect Dis [Internet]. 2015 Dec 23;15(1):386. Available from: http://bmcinfectdis.biomedcentral.com/articles/10.1186/s12879-015-1129-z

45. H. S, F. J, L. K, M. B, M. A, J. B, et al. Occupational exposures to ebola virus in ebola treatment center, conakry, guinea. Emerg Infect Dis. 2017;

46. Kesieme EB, Uwakwe K, Irekpita E, Dongo A, Bwala KJ, Alegbeleye BJ. Knowledge of Hepatitis B Vaccine among Operating Room Personnel in Nigeria and Their Vaccination Status. Hepat Res Treat [Internet]. 2011;2011:1-5. Available from: http://www.hindawi.com/journals/heprt/2011/157089/

47. Ogoina D, Pondei K, Adetunji B, Chima G, Isichei C, Gidado S. Prevalence of hepatitis B vaccination among health care workers in Nigeria in 2011-12. Int J Occup Environ Med. 2014 Jan;5(1):51-6.

48. Okwara EC, Enwere OO, Diwe CK, Azike JE, Chukwulebe AE. Theatre and laboratory workers' awareness of and safety practices against hepatitis $\mathrm{B}$ and $\mathrm{C}$ infection in a suburban university teaching hospital in Nigeria. Pan Afr Med J. 2012;13:2.

49. Omotowo IB, Meka IA, Ijoma UN, Okoli VE, Obienu O, Nwagha T, et al. Uptake of hepatitis $\mathrm{B}$ vaccination and its determinants among health care workers in a tertiary health facility in Enugu, South-East, Nigeria. BMC Infect Dis [Internet]. 2018 Dec 28;18(1):288. Available from: https://bmcinfectdis.biomedcentral.com/articles/10.1186/s12879-018-3191-9 
50. Farouq Muhammad Dayyab, Garba Iliyasu, Bashir Garba Ahmad ATB, Habib SSN and AG. Hepatitis B vaccine knowledge and self-reported vaccination status among healthcare workers in a conflict region in northeastern Nigeria. Ther Adv Vaccines Immunother. 2020;8:1-11.

51. Aaron D, Nagu TJ, Rwegasha J, Komba E. Hepatitis B vaccination coverage among healthcare workers at national hospital in Tanzania: how much, who and why? BMC Infect Dis [Internet]. 2017 Dec 20;17(1):786. Available from: https://bmcinfectdis.biomedcentral.com/articles/10.1186/s12879-017-2893-8

52. Debes JD, Kayandabila J, Pogemiller H. Knowledge of Hepatitis B Transmission Risks Among Health Workers in Tanzania. Am J Trop Med Hyg. 2016 May;94(5):1100-2.

53. Akibu M, Nurgi S, Tadese M, Tsega WD. Attitude and Vaccination Status of Healthcare Workers against Hepatitis B Infection in a Teaching Hospital, Ethiopia. Scientifica (Cairo) [Internet]. 2018;2018:1-8. Available from: https://www.hindawi.com/journals/scientifica/2018/6705305/

54. Tenna A, Stenehjem EA, Margoles L, Kacha E, Blumberg HM, Kempker RR. Infection control knowledge, attitudes, and practices among healthcare workers in Addis Ababa, Ethiopia. Infect Control Hosp Epidemiol. 2013 Dec;34(12):1289_ 96.

55. Endalkachew Mekonnen Eticha ABG. Knowledge, Attitude, and Practice of Postexposure Prophylaxis against HIV Infection among Healthcare Workers in Hiwot Fana Specialized University Hospital, Eastern Ethiopia. AIDS Res Treat. 
2019;2019.

56. Noubiap JJN, Nansseu JRN, Kengne KK, Tchokfe Ndoula S, Agyingi LA. Occupational exposure to blood, hepatitis B vaccine knowledge and uptake among medical students in Cameroon. BMC Med Educ [Internet]. 2013 Dec 8 [cited 2018 Dec 3];13(1):148. Available from: http://bmcmededuc.biomedcentral.com/articles/10.1186/1472-6920-13-148

57. Meriki HD, Tufon KA, Anong DN, Tony NJ, Kwenti TE BA. Vaccine uptake and immune responses to $\mathrm{HBV}$ infection amongst vaccinated and non-vaccinated healthcare workers, household and sexual contacts to chronically infected HBV individuals in the south west region of Cameroon. PLoS One. 2018;13(7):1-18.

58. Akazong W E, Tume C, Njouom R, Ayong L, Fondoh V, Kuiate J-R. Knowledge, attitude and prevalence of hepatitis B virus among healthcare workers: a crosssectional, hospital-based study in Bamenda Health District, NWR, Cameroon. BMJ Open [Internet]. 2020 Mar 1;10(3):e031075. Available from: http://bmjopen.bmj.com/content/10/3/e031075.abstract

59. Konlan KD, Aarah-Bapuah M, Kombat JM, Wuffele GM. The level of nurses' knowledge on occupational post exposure to hepatitis B infection in the Tamale metropolis, Ghana. BMC Health Serv Res [Internet]. 2017 Dec 5;17(1):254. Available from: http://bmchealthservres.biomedcentral.com/articles/10.1186/s12913-017-2182-7

60. Katakam P, Bader A, Chandu B, Hwisa N, Ismael M. Pandemic influenza A (H1N1) vaccination among libyan health care personnel: A cross-sectional 
retrospective study. J Pharm Bioallied Sci [Internet]. 2014 Jul;6(3):192. Available from: http://www.jpbsonline.org/text.asp?2014/6/3/192/130958

61. Ziglam H, El-Hattab M, Shingheer N, Zorgani A, Elahmer O. 1 in Tripoli, LibyHepatitis B vaccination status among healthcare workers in a tertiary care hospitaa. J Infect Public Health. 2013 Aug;6(4):300-60.

62. James PB, Rehman IU, Bah AJ, Lahai M, Cole CP, Khan TM. An assessment of healthcare professionals' knowledge about and attitude towards influenza vaccination in Freetown Sierra Leone: a cross-sectional study. BMC Public Health [Internet]. 2017 Dec 5;17(1):692. Available from: http://bmcpublichealth.biomedcentral.com/articles/10.1186/s12889-017-4700-2

63. Mbaisi EM, Ng'ang'a Z, Wanzala P, Omolo J. Prevalence and factors associated with percutaneous injuries and splash exposures among health-care workers in a provincial hospital, Kenya, 2010. Pan Afr Med J [Internet]. 2013;14:10. Available from: http://www.panafrican-med-journal.com/content/article/14/10/full/

64. McAnerney JM, Walaza S, Cohen AL, Tempia S, Buys A, Venter M, et al. Effectiveness and knowledge, attitudes and practices of seasonal influenza vaccine in primary healthcare settings in South Africa, 2010-2013. Influenza Other Respi Viruses [Internet]. 2015 May;9(3):143-50. Available from: http://doi.wiley.com/10.1111/irv.12305

65. Tine J, Diallo MB, Dabis F, Manga NM, Dia NM, Seydi M, et al. Prevention and Care of Hepatitis B in Senegal; Awareness and Attitudes of Medical Practitioners. Am J Trop Med Hyg [Internet]. 2017 Aug 2;97(2):389-95. Available from: 
http://www.ajtmh.org/content/journals/10.4269/ajtmh.17-0065

66. Kambutse I, Igiraneza G, Ogbuagu O. Perceptions of HIV transmission and preexposure prophylaxis among health care workers and community members in Rwanda. Khawcharoenporn T, editor. PLoS One [Internet]. 2018 Nov 26;13(11):e0207650. http://dx.plos.org/10.1371/journal.pone.0207650

67. Mungandi N, Makasa M, Musonda P. Hepatitis B vaccination coverage and the determinants of vaccination among health care workers in selected health facilities in Lusaka district, Zambia: an exploratory study. Ann Occup Environ Med [Internet]. 2017 Dec 10;29(1):32. Available from: http://aoemj.biomedcentral.com/articles/10.1186/s40557-017-0191-y

68. Farouq Muhammad Dayyab, Garba Iliyasu, Bashir Garba Ahmad ATB, Habib SSNAG. Hepatitis B vaccine knowledge and self-reported vaccination status among healthcare workers in a conflict region in northeastern Nigeria. Ther Adv Vaccines Immunother. 2020;8:1-11.

69. Ayalew MB, Horssa BA, Getachew N, Amare S, Getnet A. Knowledge and attitude of health care professionals regarding hepatitis B virus infection and its vaccination , University of Gondar Hospital , Ethiopia. Hepat Med. 2016;8:13542.

70. Biset Ayalew M, Adugna Horsa B. Hepatitis B Vaccination Status among Health Care Workers in a Tertiary Hospital in Ethiopia. Hepat Res Treat. 2017;2017:6470658. 
71. Geberemariyam BS, Donka GM, Wordofa B. Assessment of knowledge and practices of healthcare workers towards infection prevention and associated factors in healthcare facilities of West Arsi District, Southeast Ethiopia: a facility-based cross-sectional study. Arch Public Health. 2018;76:69.

72. Adjei CA, Asamoah R, Atibila F, Ti-enkawol GN, Ansah-Nyarko M. Mother-tochild transmission of hepatitis B: extent of knowledge of physicians and midwives in Eastern region of Ghana. BMC Public Health [Internet]. 2016 Dec 11;16(1):537. Available from: http://bmcpublichealth.biomedcentral.com/articles/10.1186/s12889-016-3215-6

73. Kouassi D, Angbo-Effi O, Aka L, Coulibaly M, Soumahoro S, Yao G, et al. Perceptions and practice of health care workers regarding hepatitis B vaccination, Bouaké, Côte d'Ivoire, 2016. J Public Health Africa [Internet]. 2017 Dec $31 ; 8(2): 715$. Available from: http://publichealthinafrica.org/index.php/jphia/article/view/715

74. Arafa AE, Mohamed AA, Anwar MM. Nurses' knowledge and practice of bloodborne pathogens and infection control measures in selected Beni-Suef Hospitals Egypt. J Egypt Public Health Assoc [Internet]. 2016 Sep;91(3):120-6. Available from:

http://content.wkhealth.com/linkback/openurl?sid=WKPTLP:landingpage $\& a n=00$ 004765-201609000-00004

75. Djaogol T, Coste M, Marcellin F, Jaquet A, Chabrol F G-VT. Prevention and care of hepatitis B in the rural region of Fatick in Senegal: a healthcare workers' 
perspective using a mixed methods approach. BMC Heal Serv Res. 2019;19(1):627.

76. Mursy S, Mohamed S. Knowledge, attitude, and practice towards Hepatitis B infection among nurses and midwives in two maternity hospitals in Khartoum, Sudan. BMC Public Health. 2019;19(1):1597.

77. Kimaro L, Adinan J, Damian DJ, Njau B. Prevalence of occupational injuries and knowledge of availability and utilization of post exposure prophylaxis among health care workers in Singida District Council, Singida Region, Tanzania. Lai PS, editor. PLoS One [Internet]. 2018 Oct 25;13(10):e0201695. Available from: http://dx.plos.org/10.1371/journal.pone.0201695

78. Mashoto KO, Mubyazi GM, Makundi E, Mohamed H, Malebo HM. Estimated risk of HIV acquisition and practice for preventing occupational exposure: a study of healthcare workers at Tumbi and Dodoma Hospitals, Tanzania. BMC Health Serv Res [Internet]. 2013 Dec 30;13(1):369. Available from: http://bmchealthservres.biomedcentral.com/articles/10.1186/1472-6963-13-369

79. Mashoto KO, Mubyazi GM, Mushi AK. Knowledge of occupational exposure to HIV: a cross sectional study of healthcare workers in Tumbi and Dodoma hospitals, Tanzania. BMC Health Serv Res [Internet]. 2015 Dec 22;15(1):29. Available from:

http://bmchealthservres.biomedcentral.com/articles/10.1186/s12913-015-0700-z

80. Mponela MJ, Oleribe OO, Abade A, Kwesigabo G. Post exposure prophylaxis following occupational exposure to HIV: a survey of health care workers in 
Mbeya, Tanzania, 2009-2010. Pan Afr Med J. 2015;21:32.

81. Kapologwe N, Mahande M, Msuya SE. Provider-initiated HIV testing and counseling in Mbeya City, south-western Tanzania: knowledge and practice of health care providers. Tanzan J Health Res. 2011 Oct;13(4):95-100.

82. Abe EO, Kolude B, Adeyemi BF. HIV TESTING IN DENTAL PRACTICE: PERCEPTION AND ATTITUDE OF DENTISTS IN SOUTHWESTERN NIGERIA. Afr J Med Med Sci. 2014 Sep;43(Suppl 1):201-8.

83. Agaba P, Agaba E, Akanbi M, Daniyam C, Ocheke A, Okeke E. Awareness and knowledge of human immunodeficiency virus post exposure prophylaxis among Nigerian Family Physicians. Niger Med J [Internet]. 2012 Jul;53(3):155. Available from: http://www.nigeriamedj.com/text.asp?2012/53/3/155/104386

84. Oche OM, Umar AS, Gana GJ, Okafoagu NC, Oladigbolu RA. Determinants of appropriate knowledge on human immunodeficiency virus postexposure prophylaxis among professional health-care workers in Sokoto, Nigeria. J Fam Med Prim care. 2018;7(2):340-5.

85. Etokidem AJ, Ogaji DS, Okokon IB. Knowledge and perception of microbicides among healthcare providers in Calabar, Nigeria. Afr Health Sci. 2014 Jun;14(2):281-7.

86. Taiwo O. Dental practice, human immunodeficiency virus transmission and occupational risks: views from a teaching hospital in Nigeria. Ann Med Health Sci Res. 2014 Jul;4(Suppl 2):S94-8. 
87. Aminde LN, Takah NF, Dzudie A, Bonko NM, Awungafac G, Teno D, et al. Occupational Post-Exposure Prophylaxis (PEP) against Human Immunodeficiency Virus (HIV) Infection in a Health District in Cameroon: Assessment of the Knowledge and Practices of Nurses. Tang JW, editor. PLoS One [Internet]. 2015 Apr 16;10(4):e0124416. Available from: https://dx.plos.org/10.1371/journal.pone.0124416

88. Phetlhu DR, Bimerew M, Marie-Modeste RR, Naidoo M, Igumbor J. Nurses' Knowledge of Tuberculosis, HIV, and Integrated HIV/TB Care Policies in Rural Western Cape, South Africa. J Assoc Nurses AIDS Care [Internet]. 2018 Nov [cited 2018 Dec 3];29(6):876-86. Available from: https://linkinghub.elsevier.com/retrieve/pii/S1055329018301237

89. Smith J, Odera DN, Chege D, Muigai EN, Patnaik P, Michaels-Strasser S, et al. Identifying the Gaps: An Assessment of Nurses' Training, Competency, and Practice in HIV Care and Treatment in Kenya. J Assoc Nurses AIDS Care [Internet]. 2016 May;27(3):322-30. Available from: https://linkinghub.elsevier.com/retrieve/pii/S1055329016000066

90. Demissie Gizaw G, Aderaw Alemu Z, Kibret KT. Assessment of knowledge and practice of health workers towards tuberculosis infection control and associated factors in public health facilities of Addis Ababa, Ethiopia: A cross-sectional study. Arch Public Health. 2015;73(1):15.

91. Temesgen C, Demissie M. Knowledge and practice of tuberculosis infection control among health professionals in Northwest Ethiopia; 2011. BMC Health 
Serv Res. 2014 Nov;14:593.

92. Belachew BTST, Abebe F. Health care providers' knowledge, attitude and perceived stigma regarding tuberculosis in a pastoralist community in Ethiopia: a cross-sectional study. BMC Health Serv Res. 2019;19:19.

93. Chukwu JN, Ukwaja KN, Ekeke N, Nwafor CC, Meka AO, Madichie NO, et al. Assessment of current practices in management of childhood TB among frontline clinicians in Southern Nigeria. Int Health. 2016 Jul;8(4):269-76.

94. Ibrahim LM, Hadjia IS, Nguku P, Waziri NE, Akhimien MO, Patrobas P, et al. Health care workers' knowledge and attitude towards TB patients under Direct Observation of Treatment in Plateau state Nigeria, 2011. Pan Afr Med J. 2014;18 Suppl 1:8.

95. Akande PA. Knowledge and practices regarding tuberculosis infection control among nurses in Ibadan, south-west Nigeria: a cross-sectional study. e BMC Heal Serv Res. 2020;20:280.

96. Malangu N, Adebanjo OD. Knowledge and practices about multidrug-resistant tuberculosis amongst healthcare workers in Maseru. African J Prim Heal Care Fam Med [Internet]. 2015 Mar 27;7(1). Available from: https://phcfm.org/index.php/phcfm/article/view/774

97. Bhebhe LT, Van Rooyen C, Steinberg WJ. Attitudes, knowledge and practices of healthcare workers regarding occupational exposure of pulmonary tuberculosis. African J Prim Heal care Fam Med. 2014 Oct;6(1):E1-6. 
98. Mugomeri E, Chatanga P, Lefunyane M, Ruhanya V, Nyandoro G, Chin'ombe N. Adherence to tuberculosis infection control guidelines by nurses in Lesotho. Am J Infect Control [Internet]. 2015 Jul;43(7):735-8. Available from: https://linkinghub.elsevier.com/retrieve/pii/S0196655315001868

99. van Rensburg AJ, Engelbrecht M, Kigozi G, van Rensburg D. Tuberculosis prevention knowledge, attitudes, and practices of primary health care nurses. Int $\mathbf{J}$ Nurs Pract. 2018 Jul;e12681.

100. Buregyeya E, Kasasa S, Mitchell EMH. Tuberculosis infection control knowledge and attitudes among health workers in Uganda: a cross-sectional study. BMC Infect Dis. 2016 Aug;16(1):416.

101. Abera B, Kibret M, Mulu W. Knowledge and beliefs on antimicrobial resistance among physicians and nurses in hospitals in Amhara Region, Ethiopia. BMC Pharmacol Toxicol [Internet]. 2014 Dec 19;15(1):26. Available from: http://bmcpharmacoltoxicol.biomedcentral.com/articles/10.1186/2050-6511-15-26

102. Chaw PS, Schlinkmann KM, Raupach-Rosin H, Karch A, Pletz MW, Huebner J, et al. Knowledge, attitude and practice of Gambian health practitioners towards antibiotic prescribing and microbiological testing: a cross-sectional survey. Trans R Soc Trop Med Hyg. 2017;111(3):117-24.

103. Labi A-K, Obeng-Nkrumah N, Bjerrum S, Aryee NAA, Ofori-Adjei YA, Yawson AE, et al. Physicians' knowledge, attitudes, and perceptions concerning antibiotic resistance: a survey in a Ghanaian tertiary care hospital. BMC Health Serv Res [Internet]. 2018 Dec 20;18(1):126. Available from: 
https://bmchealthservres.biomedcentral.com/articles/10.1186/s12913-018-2899-y

104. Fathi I, Sameh O, Abu-Ollo M, Naguib A, Alaa-Eldin R, Ghoneim D, et al. Knowledge, Attitudes, and Beliefs Regarding Antimicrobial Therapy and Resistance Among Physicians in Alexandria University Teaching Hospitals and the Associated Prescription Habits. Microb Drug Resist. 2017 Jan;23(1):71-8.

105. Isara A, Akpodiete A. Concerns about the knowledge and attitude of multidrugresistant tuberculosis among health care workers and patients in Delta State, Nigeria. Niger J Clin Pract [Internet]. 2015;18(5):664. Available from: http://www.njcponline.com/text.asp?2015/18/5/664/154212

106. Kamulegeya A, William B, Rwenyonyi CM. Knowledge and Antibiotics Prescription Pattern among Ugandan Oral Health Care Providers: A Crosssectional Survey. J Dent Res Dent Clin Dent Prospects. 2011;5(2):61-6.

107. Bulabula ANH, Jenkins A, Mehtar S, Nathwani D. Education and management of antimicrobials amongst nurses in Africa-a situation analysis $\square$ : An Infection Control Africa Network ( ICAN )/ BSAC online survey Education and management of antimicrobials amongst nurses in Africa — a situation analysis $\square$ : an Inf. J Antimicrob Chemother. 2018;73(5):1408-15.

108. Adegboye MB, Zakari S, Ahmed BA, Olufemi GH. Knowledge, awareness and practice of infection control by health care workers in the intensive care units of a tertiary hospital in Nigeria. Afr Health Sci [Internet]. 2018 Apr 4;18(1):72. Available from: https://www.ajol.info/index.php/ahs/article/view/169136 
109. Ijarotimi IT, Ilesanmi OS, Aderinwale A, Abiodun-Adewusi O, Okon I-M. Knowledge of Lassa fever and use of infection prevention and control facilities among health care workers during Lassa fever outbreak in Ondo State, Nigeria. Pan Afr Med J. 2018;30:56.

110. Ndu AC, Arinze-Onyia SU. Standard precaution knowledge and adherence: Do Doctors differ from Medical Laboratory Scientists? Malawi Med J. 2017 Dec;29(4):294-300.

111. Fadeyi A, Fowotade A, Abiodun MO, Jimoh AK, Nwabuisi C, Desalu OO. Awareness and practice of safety precautions among healthcare workers in the laboratories of two public health facilities in Nigeria. Niger Postgrad Med J. 2011 Jun;18(2):141-6.

112. Olalekan Adebimpe W. Knowledge, Attitude, and Practice of Use of Safety Precautions Among Health Care Workers in a Nigerian Tertiary Hospital, 1 Year After the Ebola Virus Disease Epidemic. Ann Glob Heal [Internet]. 2017 Mar $8 ; 82(5): 897$. Available from: https://annalsofglobalhealth.org/article/10.1016/j.aogh.2016.07.004/

113. Oli AN, Okoli KC, Ujam NT, Adje DU, Ezeobi I. Health professionals knowledge about relative prevalence of hospital-acquired infections in Delta State of Nigeria. Pan Afr Med J [Internet]. 2016;24:148. Available from: http://www.panafrican-med-journal.com/content/article/24/148/full/

114. Desta M, Ayenew T, Sitotaw N, Tegegne N, Dires M, Getie M. Knowledge, practice and associated factors of infection prevention among healthcare workers 
in Debre Markos referral hospital, Northwest Ethiopia. BMC Health Serv Res [Internet]. 2018 Jun;18(1):465. Available from: http://www.ncbi.nlm.nih.gov/pubmed/29914477\%0Ahttp://www.pubmedcentral.ni h.gov/articlerender.fcgi?artid=PMC6006704

115. Kebede A, Gerensea H. Prevalence of needle stick injury and its associated factors among nurses working in public hospitals of Dessie town, Northeast Ethiopia, 2016. BMC Res Notes [Internet]. 2018 Dec 28;11(1):413. Available from: https://bmcresnotes.biomedcentral.com/articles/10.1186/s13104-018-3529-9

116. Kamulegeya A, Kizito AN, Balidawa H. Ugandan medical and health sciences interns' infection control knowledge and practices. J Infect Dev Ctries [Internet]. 2013 Oct 15;7(10):726-33. from: http://www.jidc.org/index.php/journal/article/view/2486

117. Sethi AK, Acher CW, Kirenga B, Mead S, Donskey CJ, Katamba A. Infection Control Knowledge, Attitudes, and Practices among Healthcare Workers at Mulago Hospital, Kampala, Uganda. Infect Control Hosp Epidemiol [Internet]. 2012 Sep 2;33(09):917-23. Available from: https://www.cambridge.org/core/product/identifier/S0195941700031532/type/jour nal_article

118. Chemoiwa RK, Mukthar VK, Maranga AK, Kulei SJ. NURSES INFECTION PREVENTION PRACTICES IN HANDLING INJECTIONS: A CASE OF RIFT VALLEY PROVINCIAL HOSPITAL IN KENYA. East Afr Med J. 2014 Oct;91(10):361-7. 
119. Olu O, Kargbo B, Kamara S, Wurie AH, Amone J, Ganda L, et al. Epidemiology of Ebola virus disease transmission among health care workers in Sierra Leone, May to December 2014: a retrospective descriptive study. BMC Infect Dis. 2015 Oct; $15: 416$.

120. Ibekwe RU, Adam VY. Injection safety practices among resident doctors in a tertiary health facility in Benin City. Niger J Clin Pract. 2014;17(4):403-6.

121. Audu BM, Bukar M, Ibrahim AI, Swende TZ. Awareness and perception of human papilloma virus vaccine among healthcare professionals in Nigeria. J Obstet Gynaecol (Lahore). 2014;34(8):714-7.

122. Ekeke N, Meka AO, Chukwu JN, Nwafor CC, Alphonsus C, Mbah OK, et al. Assessment of health care workers' knowledge, attitude and risk perception of Buruli ulcer disease in Southern Nigeria. Trans R Soc Trop Med Hyg. 2017 May;111(5):226-32.

123. Ilesanmi F, Ilesanmi O. Knowledge of aflatoxin contamination in groundnut and the risk of its ingestion among health workers in Ibadan, Nigeria. Asian Pac J Trop Biomed [Internet]. 2011 Dec;1(6):493-5. Available from: http://linkinghub.elsevier.com/retrieve/pii/S2221169111601081

124. Benon AB, Juliet K, Samuel M, Catherine K, Benjamin S, Michael M, et al. Health workers' knowledge of zoonotic diseases in an endemic region of Western Uganda. Zoonoses Public Health. 2018;65(7):850-8.

125. Harrowing JN. Compassion practice by Ugandan nurses who provide HIV care. 
Online J Issues Nurs. 2011 Jan;16(1):5.

126. Coulibaly D, Nzussouo NT, Kadjo HA, Traoré Y, Ekra DK. Pandemic Influenza A ( H1N1 ) in Cote d' Ivoire $\square$ : health-care providers' knowledge of influenza and attitudes towards vaccination Emerging Problems In Infectious Diseases Pandemic Influenza A ( H1N1 ) in Cote d' Ivoire $\square$ : health- care providers' knowle. J Infect Dev Ctries. 2013;7(7):499-506.

127. Emmanuel Armand Kouotou, Jobert Richie N. Nansseu, Alexandra Dominique Ngangue Engome SAT and ACZ-KB. Knowledge, attitudes and practices of the medical personnel regarding atopic dermatitis in Yaoundé, Cameroon. Vol. 17, BMC Dermatology. England; 2017. p. 1-7.

128. Gemeda DH, Sime AG, Hajito KW, Gelalacha BD, Tafese W, Gebrehiwot TT. Health Care Providers' Knowledge and Practice Gap towards Joint Zoonotic Disease Surveillance System: Challenges and Opportunities, Gomma District, Southwest Ethiopia. Biomed Res Int. 2016;2016:3942672.

129. Kajeguka DC, Desrochers RE, Mwangi R, Mgabo MR, Alifrangis M, Kavishe RA, et al. Knowledge and practice regarding dengue and chikungunya: a crosssectional study among Healthcare workers and community in Northern Tanzania. Trop Med Int Heal [Internet]. 2017 May;22(5):583-93. Available from: http://doi.wiley.com/10.1111/tmi.12863

130. Sharma S, Tyagi A, Ramachandra S, Bhuyan L, Dash KC, Raghuvanshi M. Knowledge, Attitudes, and Practices among Health-Care Providers Regarding Zika Virus Infection. J Int Soc Prev Community Dent. 2018;8(1):41-7. 
131. Coppola N, De Pascalis S, Onorato L, Calò F, Sagnelli C, Sagnelli E. Hepatitis B virus and hepatitis $\mathrm{C}$ virus infection in healthcare workers. World $\mathrm{J}$ Hepatol [Internet]. $2016 \quad$ Feb $18 ; 8(5): 273-81 . \quad$ Available from: https://pubmed.ncbi.nlm.nih.gov/26925201

132. Pustil R. Global AIDS. AIDS. 2003;17 Suppl 4:S3-11.

133. UNAIDS. Global Report: Global AIDS epidemics. 2012.

134. Okere NE, Urlings L, Naniche D, de Wit TFR, Gomez GB, Hermans S. Evaluating the sustainability of differentiated service delivery interventions for stable ART clients in sub-Saharan Africa: a systematic review protocol. BMJ Open [Internet]. 2020 Feb 2;10(1):e033156-e033156. Available from: https://pubmed.ncbi.nlm.nih.gov/32014874

135. Tawfik L, Kinoti SN. The impact of HIV/AIDS on the health workforce in developing countries [Internet]. 2006 [cited 2021 Jan 21]. Available from: https://www.who.int/hrh/documents/Impact_of_HIV.pdf?ua=1

136. Pai M, Joshi R, Dogra S, Deepak K Mendiratta, Pratibha Narang, Shriprakash Kalantri ALR, Jr JMC, Riley LW, et al. Serial testing of health care workers for tuberculosis using interferon-gamma assay. Am J Respir Crit Care Med. 174(3):349-55.

137. Christopher DJ, James P, Daley P, Armstrong L, Barney T J Isaac BT, Premkumar B, et al. High annual risk of tuberculosis infection among nursing students in South India: a cohort study. PLoS One. 2011;6(10):e26199. 
138. Mohanty A, Kabi A, Mohanty AP. Health problems in healthcare workers: A review. J Fam Med Prim care [Internet]. 2019 Aug 28;8(8):2568-72. Available from: https://pubmed.ncbi.nlm.nih.gov/31548933

139. World Health Organization. Strategic directions for strengthening nursing and midwifery services 2011-2015 [Internet]. [cited 2021 Jan 22]. Available from: https://apps.who.int/iris/bitstream/handle/10665/70526/WHO_HRH_HPN_10.1_it a.pdf

140. World Health Organization. Global health-sector strategy for HIV/AIDS 20032007. [Internet]. [cited 2021 Jan 22]. Available from: https://www.aidsactioneurope.org/en/publication/global-health-sector-strategyhivaids-2003-2007-providing-framework-partnership-and

141. World Health Organization. GLOBAL HIV/AIDS RESPONSE: Epidemic update and health sector progress towards Universal Access [Internet]. 2011. Available from:

https://www.unaids.org/sites/default/files/media_asset/20111130_UA_Report_en_ 1.pdf

142. Centers for Disease Control and Prevention. Workbook for Designing, Implementing and Evaluating a Sharps Injury Prevention Program 2008 [Internet]. [cited Jan 17]. Available from: http://www.cdc.gov/sharpssafety/pdf/sharpsworkbook_2008.pdf

143. Eucomed. European healthcare workers at risk! [Internet]. [cited 2021 Jan 17]. Available from: http://saferneedles.org.uk/?page $=41 \& i d=60$ 
144. Martin C, Locke S, Sagar M, Symon S, Pelman G, Noertjojo K. Protecting healthcare workers from occupational exposure to bloodborne pathogens the role of WorkSafeBC: World Health Organization. [Internet]. [cited 2021 Jan 17]. Available from: https://www.who.int/occupational_health/gohnet_17_finalrevised.pdf

145. Thapa PK. Strategies for reducing needlestick injuries among healthcare workers; A literature review [Internet]. Arcada University of Applied Science; 2016. Available from: https://www.theseus.fi/bitstream/handle/10024/112790/Thesis Puja.pdf?sequence $=1 \&$ is Allowed $=\mathrm{y}$

146. Maltezou HC, Poland GA. Vaccination policies for healthcare workers in Europe. Vaccine. 2014;32(38):4876-80.

147. World Health Organization. Hepatitis B [Internet]. 2020 [cited 2021 Jan 23]. Available from: https://www.who.int/en/news-room/fact-sheets/detail/hepatitis-b

148. Ciorlia LAS, Zanetta DMT. Hepatitis B in Healthcare Workers $\square$ : Prevalence , Vaccination and Relation to Occupational Factors. 2005;9:384-9.

149. Batra V, Goswami A, Dadhich S, Kothari D, Bhargava N. Hepatitis B immunization in healthcare workers. Ann Gastroenterol. 2015;28(2):276-80.

150. HK K, OA A. HBV Serological Profiles and Vaccination Status among Healthcare Workers in Istanbul, Turkey. J Anc Dis Prev Remedies. 2015;03(01):2013-6.

151. Prüss-Ustün A, Rapiti E, Hutin Y. Estimation of the global burden of disease attributable to contaminated sharps injuries among health-care workers. Am J Ind 
Med. 2005;48(6):482-90.

152. Yuan Q, Wang F, Zheng H, Zhang G, Miao N, Sun X, et al. Hepatitis B vaccination coverage among health care workers in China. PLoS One [Internet]. 2019 May 7;14(5):e0216598-e0216598. Available from: https://pubmed.ncbi.nlm.nih.gov/31063488

153. Attaullah S, Khan S, Naseemullah, Ayaz S, Khan SN, Ali I, et al. Prevalence of HBV and HBV vaccination coverage in health care workers of tertiary hospitals of Peshawar, Pakistan. Virol J. 2011;8(1):275.

154. Aishwarya N, Rao D, Hk M. Knowledge about Hepatitis B and Vaccination Status among Healthcare Workers in a Tertiary Care Teaching Hospital, Mysuru. 2016;6(March):231-6.

155. Jalaleddin Hamissi Z. Knowledge, Attitudes and Practice of Hepatitis B vaccination among Iranian dentists. Int J Collab Res Intern Med Public Heal. 2014;6(7):199-206.

156. Fortunato F, Tafuri S, Cozza V, Martinelli D, Prato R. Low vaccination coverage among italian healthcare workers in 2013. Hum Vaccin Immunother [Internet]. 2014/11/01. 2015;11(1):133-9. Available from: https://pubmed.ncbi.nlm.nih.gov/25483526

157. Maltezou HC, Katerelos P, Poufta S, Pavli A, Maragos A, Theodoridou M. Attitudes toward mandatory occupational vaccinations and vaccination coverage against vaccine-preventable diseases of health care workers in primary health care 
centers. Am J Infect Control. 2013;41(1):66-70.

158. Vardhini H, Selvaraj N, Meenakshi R. Assessment on knowledge and practice of postexposure prophylaxis of human immuno-deficiency virus among staff nurses and paramedical workers at a tertiary care hospital in South India. J Educ Heal Promot. 2020;9:279.

159. Jovic-Vranes A, Jankovic S, Vukovic D, Vranes B, Miljus D. Risk perception and attitudes towards HIV in Serbian health care workers. Occup Med (Chic Ill). 2006;56(4):275-8.

160. Shahar E, Maor C, Moshe-Eilon Y. Medical personnel knowledge and stigmatic attitude toward HIV patients in a high-income country. AIDS Care - Psychol Socio-Medical Asp AIDS/HIV. 2020;32(8):1023-9.

161. Noaman AM, Medicine C. K A P S t u d y a b o u t H e p a t i t is B a m ong M e d i c a 1 a nd Para medic a $1 \mathrm{~S}$ t a f f i n T i k r i C i t y. Tikrit Med J. 2012;18(2):261-8.

162. Hussain S, Patrick N, Shams R. Hepatitis B and C prevalence and prevention awareness among health care workers in a tertiary care hospital. Int $\mathbf{J}$ Pathol. 2010;8(1):16-21.

163. World Health Organization. Global tuberculosis report 2019 (WHO/CDS/TB/2019.15). [Internet]. Geneva, Switzerland.; 2019. Available from: https:www.who.int/tb/publications/global_report/en/

164. World Health Organization. Guidelines for the prevention of tuberculosis in 
healthcare facilities in resource-limited settings [Internet]. Geneva, Switzerland.; 2005 [cited 2021 Jan 28]. Available from: www.who.int/docstore/gtb/\%0Apublications/healthcare/PDF/ WHO99-269.pdf

165. Jensen PA, Lambert LA, Michael F Iademarco, Renee Ridzon C. Guidelines for preventing the transmission of Mycobacterium tuberculosis in health-care settings, 2005. MMWR Recomm Rep. 2005;54(RR-17):1-141.

166. Bhebhe LT, Van Rooyen C, Steinberg WJ. Attitudes, knowledge and practices of healthcare workers regarding occupational exposure of pulmonary tuberculosis. African J Prim Heal care Fam Med [Internet]. 2014 Oct 17;6(1):E1-6. Available from: https://pubmed.ncbi.nlm.nih.gov/26245412

167. Biscotto C, Pedroso E, Starling C, Roth V. Evaluation of N95 respirator use as a tuberculosis control measure in a resource-limited setting. Int J Tuberc Lung Dis. 2005 Jun 1;9:545-9.

168. Vila J, Pál T. Update on Antibacterial Resistance in Low-Income Countries: Factors Favoring the Emergence of Resistance. Open Infect Dis J. 2010 Sep 15;4.

169. Navarro-San Francisco C, Del Toro MD, Cobo J, De Gea-García JH, Vañó-Galván S, Moreno-Ramos F, et al. Knowledge and perceptions of junior and senior Spanish resident doctors about antibiotic use and resistance: Results of a multicenter survey. Enferm Infecc Microbiol Clin [Internet]. 2013;31(4):199-204. Available from: http://www.sciencedirect.com/science/article/pii/S0213005X12002169 
170. Pulcini C, Williams F, Molinari N, Davey P, Nathwani D. Junior doctors' knowledge and perceptions of antibiotic resistance and prescribing: a survey in France and Scotland. Clin Microbiol Infect [Internet]. 2011 Jan 1;17(1):80-7. Available from: https://doi.org/10.1111/j.1469-0691.2010.03179.x

171. denis K. Antimicrobial Resistance in Developing Countries and Responsible Risk Factors. Int J Antimicrob Agents. 2004 Sep 1;24:105-10.

172. Parmeggiani C, Abbate R, Marinelli P, Angelillo IF. Healthcare workers and health care-associated infections: knowledge, attitudes, and behavior in emergency departments in Italy. BMC Infect Dis [Internet]. 2010;10(1):35. Available from: https://doi.org/10.1186/1471-2334-10-35

173. Gammon J, Morgan-Samuel H, Gould D. A review of the evidence for suboptimal compliance of healthcare practitioners to standard/universal infection control precautions. J Clin Nurs. 17(2):157-67. 
medRxiv preprint doi: https://doi.org/10.1101/2021.10.14.21264931; this version posted October 16, 2021. The copyright holder for this preprint (which was not certified by peer review) is the author/funder, who has granted medRxiv a license to display the preprint in perpetuity.

$$
\text { It is made available under a CC-BY-ND } 4.0 \text { International license. }
$$


medRxiv preprint doi: https://doi.org/10.1101/2021.10.14.21264931; this version posted October 16, 2021. The copyright holder for this preprint (which was not certified by peer review) is the author/funder, who has granted medRxiv a license to display the preprint in perpetuity.

\section{It is made available under a CC-BY-ND 4.0 International license .}
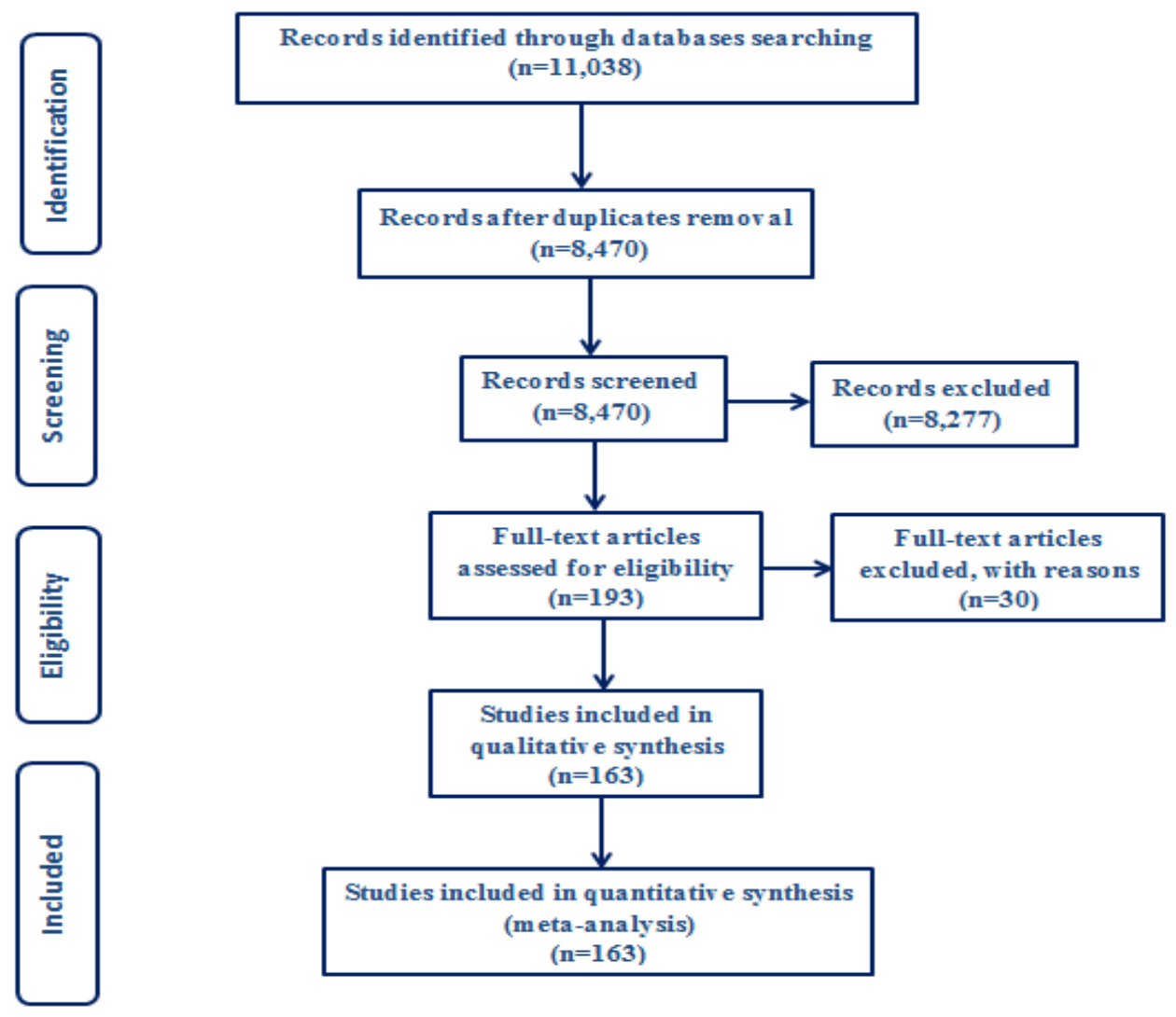

Figure 1. Literature search and selection of studies (PRISMA flow diagram) 
medRxiv preprint doi: https://doi.org/10.1101/2021.10.14.21264931; this version posted October 16, 2021. The copyright holder for this preprint (which was not certified by peer review) is the author/funder, who has granted medRxiv a license to display the preprint in perpetuity.

It is made available under a CC-BY-ND 4.0 International license .

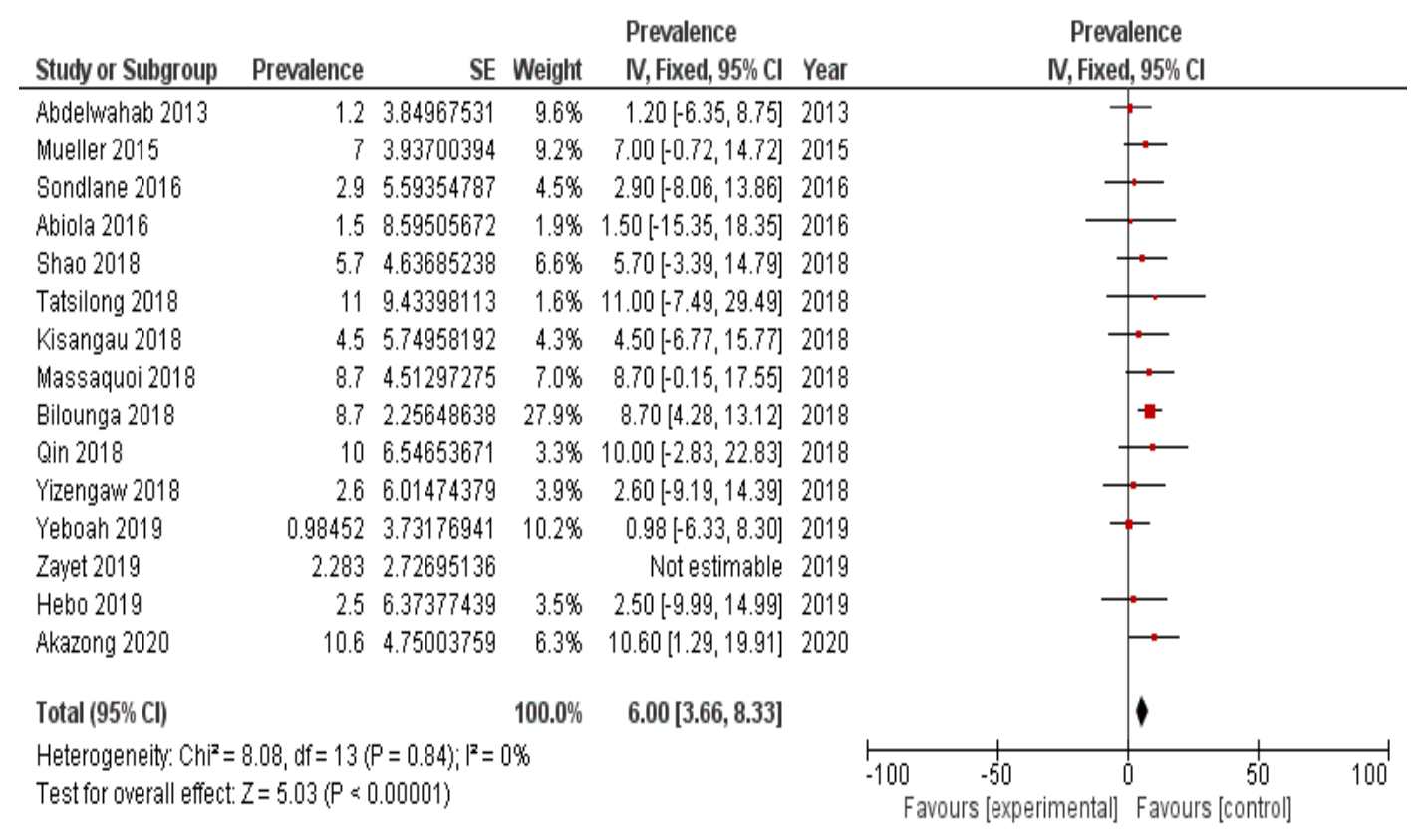

Figure 2. Prevalence of HBV (HBsAg) among African HCWs from studies included in the review.

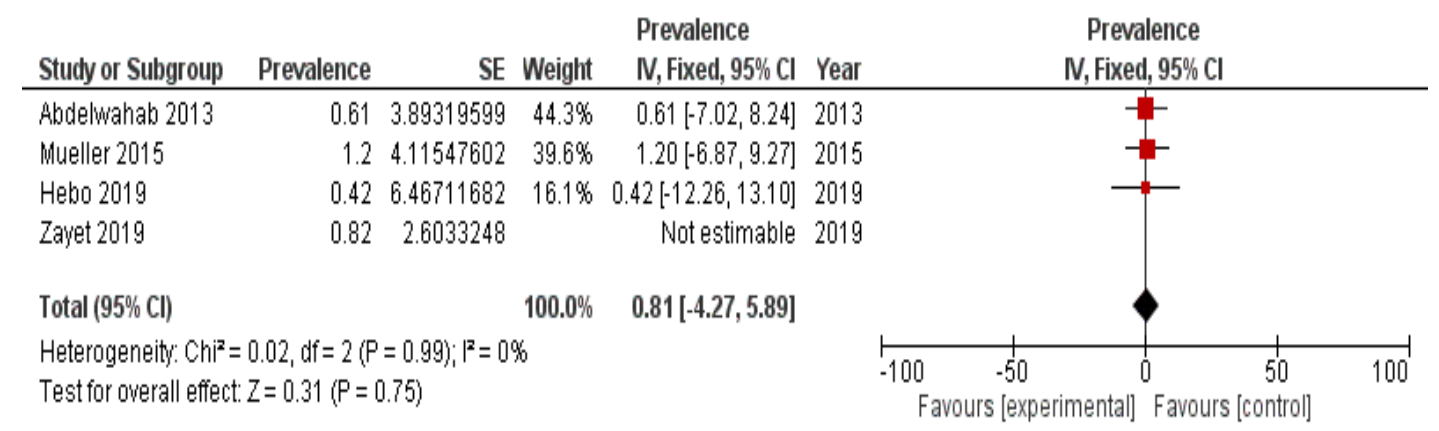

Figure 3. Prevalence of HCV (anti-HCV) among African HCWs from studies included in this review. 
Table 1. Prevalence of microbiological infections among African HCWs

\begin{tabular}{|c|c|c|c|c|c|c|c|}
\hline Variable & Countries & $\begin{array}{l}\text { Total } \\
\text { sample size }\end{array}$ & References & Pooled prevalence & Heterogeneity & $\begin{array}{l}\text { Test for } \\
\text { overall effect }\end{array}$ & $\begin{array}{l}\text { Type } \\
\text { effect }\end{array}$ \\
\hline HBsAg-positive & $\begin{array}{lr}\text { Cameroon, } & \text { Kenya, } \\
\text { Sierra } & \text { Leone, } \\
\text { Tanzania, } & \text { South } \\
\text { Africa, } & \text { Ethiopia, } \\
\text { Egypt, } & \text { Nigeria, } \\
\text { Ghana } & \end{array}$ & 6599 & $\begin{array}{l}(23)(24)(25)(36) \\
(35) \\
(44)(31)(16)(17) \\
(33)(39)(40)(37) \\
(27)\end{array}$ & $6.00[3.66,8.33]$ & $\begin{array}{l}\text { Chi }^{2}=8.08, \text { df }= \\
13(\mathrm{P}=0.84) ; \mathrm{I}^{2}= \\
0 \%\end{array}$ & $\begin{array}{l}Z=5.03(P< \\
0.00001)\end{array}$ & Fixed Effect \\
\hline anti-HCV-positive & $\begin{array}{l}\text { Tanzania, } \quad \text { Egypt, } \\
\text { Ethiopia }\end{array}$ & 1489 & $(23)(39)(17)$ & $0.81[-4.27,5.89]$ & $\begin{array}{l}\mathrm{Chi}^{2}=0.02, \mathrm{df}=2 \\
(\mathrm{P}=0.99) ; \mathrm{I}^{2}=0 \%\end{array}$ & $\begin{array}{l}Z=0.31(P= \\
0.75)\end{array}$ & Fixed Effect \\
\hline HIV-positive & $\begin{array}{l}\text { Cameroon, } \\
\text { Africa, Kenya }\end{array}$ & 1705 & $(18)(26)(32)$ & $9.06[-6.03,24.16]$ & $\begin{array}{l}\mathrm{Tau}^{2}=157.14 \\
\mathrm{Chi}^{2}=18.59, \mathrm{df}= \\
2(\mathrm{P}<0.0001) ; \mathrm{I}^{2} \\
=89 \%\end{array}$ & $\begin{array}{l}\mathrm{Z}=1.18(\mathrm{P}= \\
0.24)\end{array}$ & $\begin{array}{l}\text { Random } \\
\text { Effect }\end{array}$ \\
\hline $\begin{array}{l}\text { S. aureus (nasal } \\
\text { colonization) }\end{array}$ & $\begin{array}{ll}\text { Ghana, } & \text { Sudan, } \\
\text { Madagascar } & \end{array}$ & 1093 & $(42)(38)(43)$ & $13.36[7.87,18.85]$ & $\begin{array}{l}\mathrm{Chi}^{2}=3.66, \mathrm{df}=2 \\
(\mathrm{P}=0.16) ; \mathrm{I}^{2}= \\
45 \%\end{array}$ & $\begin{array}{l}\mathrm{Z}=4.77(\mathrm{P}< \\
0.00001)\end{array}$ & Fixed Effect \\
\hline $\begin{array}{l}\text { Occupational } \\
\text { exposure to blood- } \\
\text { borne viruses (HBV, } \\
\mathrm{HCV} \text { and HIV) }\end{array}$ & Ethiopia, Tanzania & 1017 & $(15)(17)(18)(32)$ & $\begin{array}{l}81.20 \\
92.82]\end{array} \quad[69.57$, & $\begin{array}{l}\mathrm{Tau}^{2}=321.92 \\
\mathrm{Chi}^{2}=150.36, \mathrm{df} \\
=4(\mathrm{P}<0.00001) \\
\mathrm{I}^{2}=97 \%\end{array}$ & $\begin{array}{l}\mathrm{Z}=8.38(\mathrm{P}< \\
0.00001)\end{array}$ & $\begin{array}{l}\text { Random } \\
\text { Effect }\end{array}$ \\
\hline $\begin{array}{lr}\text { Latent TB } & \text { (LTB)- } \\
\text { positive } & \text { by } \\
\text { tuberculin } & \text { skin test } \\
\text { (TST) } & \end{array}$ & $\begin{array}{l}\text { South Africa, Kenya, } \\
\text { Mozambique }\end{array}$ & 1436 & $(28)(34)(41)$ & $\begin{array}{l}59.82 \quad[36.90, \\
82.75]\end{array}$ & $\begin{array}{l}\mathrm{Tau}^{2}=397.14 ; \\
\mathrm{Chi}^{2}=104.19, \mathrm{df} \\
=2(\mathrm{P}<0.00001) \\
\mathrm{I}^{2}=98 \%\end{array}$ & $\begin{array}{l}\mathrm{Z}=5.12(\mathrm{P}< \\
0.00001)\end{array}$ & $\begin{array}{l}\text { Random } \\
\text { Effect }\end{array}$ \\
\hline $\begin{array}{l}\text { Needle stick injury } \\
\text { (once) }\end{array}$ & $\begin{array}{l}\text { Egypt, Ethiopia, } \\
\text { Sierra Leone }\end{array}$ & 1230 & $(18)(36)(20)(39)$ & $14.68[9.55,19.80]$ & $\begin{array}{l}\mathrm{Chi}^{2}=1.93, \mathrm{df}=3 \\
(\mathrm{P}=0.59) ; \mathrm{I}^{2}=0 \%\end{array}$ & $\begin{array}{l}Z=5.61(P< \\
0.00001)\end{array}$ & Fixed Effect \\
\hline $\begin{array}{l}\text { Needle stick injury } \\
\text { (twice) }\end{array}$ & $\begin{array}{l}\text { Egypt, Ethiopia, } \\
\text { Sierra Leone }\end{array}$ & 1035 & $(18)(36)(39)$ & $16.18[-0.68,33.04]$ & $\begin{array}{l}\mathrm{Tau}^{2}=191.80 \\
\mathrm{Chi}^{2}=15.52, \mathrm{df}= \\
2(\mathrm{P}=0.0004) ; \mathrm{I}^{2} \\
=87 \%\end{array}$ & $\begin{array}{l}\mathrm{Z}=1.88(\mathrm{P}= \\
0.06)\end{array}$ & $\begin{array}{l}\text { Random } \\
\text { Effect }\end{array}$ \\
\hline
\end{tabular}




\begin{tabular}{|c|c|c|c|c|c|c|c|}
\hline $\begin{array}{l}\text { History of exposure } \\
\text { to needle stick injury } \\
\text { (at least once) }\end{array}$ & Ethiopia, Tanzania & 1830 & $\begin{array}{l}(18)(32)(21)(31) \\
(20)\end{array}$ & $\begin{array}{l}26.81 \\
39.05]\end{array} \quad[14.58$, & $\begin{array}{l}\mathrm{Tau}^{2}=211.99 \\
\mathrm{Chi}^{2}=63.30, \mathrm{df}= \\
5(\mathrm{P}<0.00001) ; \mathrm{I}^{2} \\
=92 \%\end{array}$ & $\begin{array}{l}\mathrm{Z}=4.30(\mathrm{P}< \\
0.0001)\end{array}$ & $\begin{array}{l}\text { Random } \\
\text { Effect }\end{array}$ \\
\hline $\begin{array}{l}\text { History of exposure } \\
\text { to blood or body } \\
\text { fluids on intact skin }\end{array}$ & $\begin{array}{l}\text { Ethiopia, Tanzania, } \\
\text { Guinea }\end{array}$ & 847 & $(15)(32)(45)$ & $\begin{array}{l}68.57 \quad[38.66, \\
98.49]\end{array}$ & $\begin{array}{l}\mathrm{Tau}^{2}=684.77 \\
\mathrm{Chi}^{2}=115.71, \mathrm{df} \\
=2(\mathrm{P}<0.00001) \\
\mathrm{I}^{2}=98 \%\end{array}$ & $\begin{array}{l}\mathrm{Z}=4.49(\mathrm{P}< \\
0.00001)\end{array}$ & $\begin{array}{l}\text { Random } \\
\text { Effect }\end{array}$ \\
\hline $\begin{array}{l}\text { History of splash of } \\
\text { blood or body fluids } \\
\text { to eye or mouth }\end{array}$ & Ethiopia, Tanzania & 1417 & $(15)(21)(31)$ & $\begin{array}{l}64.15 \\
88.61]\end{array} \quad[39.69$, & $\begin{array}{l}\mathrm{Tau}^{2}=459.86 \\
\mathrm{Chi}^{2}=134.64, \mathrm{df} \\
=2(\mathrm{P}<0.00001) \\
\mathrm{I}^{2}=99 \%\end{array}$ & $\begin{array}{l}\mathrm{Z}=5.14(\mathrm{P}< \\
0.00001)\end{array}$ & $\begin{array}{l}\text { Random } \\
\text { Effect }\end{array}$ \\
\hline $\begin{array}{l}\text { Sharps injury (at } \\
\text { least once) for one } \\
\text { year }\end{array}$ & $\begin{array}{l}\text { Ethiopia, South } \\
\text { Africa }\end{array}$ & 1307 & $(19)(20)(22)(29)$ & $\begin{array}{l}27.83 \\
41.37]\end{array} \quad[14.29$, & $\begin{array}{l}\mathrm{Tau}^{2}=166.53 \\
\mathrm{Chi}^{2}=25.24, \mathrm{df}= \\
3(\mathrm{P}<0.0001) ; \mathrm{I}^{2} \\
=88 \%\end{array}$ & $\begin{array}{l}\mathrm{Z}=4.03(\mathrm{P}< \\
0.0001)\end{array}$ & $\begin{array}{l}\text { Random } \\
\text { Effect }\end{array}$ \\
\hline
\end{tabular}

Table 2. Vaccination status of African HCWs

\begin{tabular}{|c|c|c|c|c|c|c|c|}
\hline Questions & Countries & $\begin{array}{l}\text { Total } \\
\text { sample size }\end{array}$ & References & Pooled prevalence & Heterogeneity & $\begin{array}{l}\text { Test for } \\
\text { overall effect }\end{array}$ & $\begin{array}{l}\text { Type } \\
\text { effect }\end{array}$ \\
\hline $\begin{array}{l}\text { Did you take only } \\
\text { one dose of the } \\
\text { hepatitis B vaccine? }\end{array}$ & $\begin{array}{l}\text { Tanzania, Nigeria, } \\
\text { Ethiopia, Cameroon, } \\
\text { Ghana }\end{array}$ & 7245 & $\begin{array}{l}(51)(40)(53)(23) \\
(30)(49)(50)(37)\end{array}$ & $14.99[5.73,24.26]$ & $\begin{array}{l}\mathrm{Tau}^{2}=153.53 ; \\
\mathrm{Chi}^{2}=68.05, \mathrm{df}= \\
7(\mathrm{P}<0.00001) ; \mathrm{I}^{2} \\
=90 \%\end{array}$ & $\begin{array}{l}\mathrm{Z}=3.17(\mathrm{P}= \\
0.002)\end{array}$ & $\begin{array}{l}\text { Random } \\
\text { Effect }\end{array}$ \\
\hline $\begin{array}{l}\text { Did you take two } \\
\text { doses of the hepatitis } \\
\text { B vaccine? }\end{array}$ & $\begin{array}{l}\text { Tanzania, Nigeria, } \\
\text { Ethiopia, Cameroon, } \\
\text { Ghana }\end{array}$ & 7245 & $\begin{array}{l}(51)(40)(53)(23) \\
(30)(49)(50)(37)\end{array}$ & $10.53[7.74,13.33]$ & $\begin{array}{l}\mathrm{Chi}^{2}=11.72, \mathrm{df}= \\
7(\mathrm{P}=0.11) ; \mathrm{I}^{2}= \\
40 \%\end{array}$ & $\begin{array}{l}\mathrm{Z}=7.39(\mathrm{P}< \\
0.00001)\end{array}$ & $\begin{array}{l}\text { Random } \\
\text { Effect }\end{array}$ \\
\hline $\begin{array}{l}\text { Did you take the } \\
\text { three doses of the } \\
\text { hepatitis B vaccine? }\end{array}$ & $\begin{array}{l}\text { Tanzania, Nigeria, } \\
\text { Ethiopia. Cameroon, } \\
\text { Kenya, } \quad \text { Ghana, } \\
\text { Zambia, } \quad \text { South }\end{array}$ & 12036 & $\begin{array}{l}(51)(40)(53)(23) \\
(30)(49)(15)(33) \\
(59)(63)(57)(67) \\
(47)(48)(27)(24)\end{array}$ & $\begin{array}{l}43.22 \\
55.21]\end{array}$ & $\begin{array}{l}\mathrm{Tau}^{2}=677.27 ; \\
\mathrm{Chi}^{2}=1209.45, \mathrm{df} \\
=18 \quad(\mathrm{P} \quad< \\
0.00001) ; \mathrm{I}^{2}=\end{array}$ & $\begin{array}{l}\mathrm{Z}=7.06(\mathrm{P}< \\
0.00001)\end{array}$ & $\begin{array}{l}\text { Random } \\
\text { Effect }\end{array}$ \\
\hline
\end{tabular}




\begin{tabular}{|c|c|c|c|c|c|c|c|}
\hline & Africa, Libya & & $(61)(50)(37)$ & & $99 \%$ & & \\
\hline $\begin{array}{l}\text { Are } \\
\text { unvaccinated against } \\
\text { HBV? }\end{array}$ & $\begin{array}{l}\text { Tanzania, Nigeria, } \\
\text { Ethiopia, Cameroon, } \\
\text { Libya }\end{array}$ & 7123 & $\begin{array}{l}(51)(40)(53)(23) \\
(15)(52)(46)(57) \\
(31)(20)(61)(50) \\
(37)\end{array}$ & $\begin{array}{l}58.42 \\
74.57]\end{array} \quad[42.27$, & $\begin{array}{l}\mathrm{Tau}^{2}=800.38 ; \\
\mathrm{Chi}^{2}=1401.22, \mathrm{df} \\
=\quad 11 \quad(\mathrm{P} \quad< \\
0.00001) ; \mathrm{I}^{2}= \\
99 \%\end{array}$ & $\begin{array}{l}Z=7.09(P< \\
0.00001)\end{array}$ & $\begin{array}{l}\text { Random } \\
\text { Effect }\end{array}$ \\
\hline $\begin{array}{lr}\text { Are you } & \text { fully } \\
\text { vaccinated } & \text { against } \\
\text { HBV? } & \end{array}$ & $\begin{array}{l}\text { Tanzania, Ethiopia, } \\
\text { Sierra Leone, Libya, } \\
\text { Ghana, South Africa, } \\
\text { Zambia, Senegal, } \\
\text { Nigeria, Cameroon }\end{array}$ & 4554 & $\begin{array}{l}(46)(31)(53)(62) \\
(60)(59)(64)(30) \\
(67)(36)(54)(65) \\
(50)(58)\end{array}$ & $\begin{array}{ll}41.86 & {[28.09,} \\
55.64] & \end{array}$ & 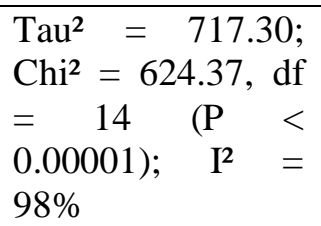 & $\begin{array}{l}Z=5.96(P< \\
0.00001)\end{array}$ & $\begin{array}{l}\text { Random } \\
\text { Effect }\end{array}$ \\
\hline $\begin{array}{l}\text { Did you take any } \\
\text { dose of the hepatitis } \\
\text { B vaccine? }\end{array}$ & $\begin{array}{l}\text { Ethiopia, } \\
\text { Cameroon, } \\
\text { Kigeria, } \\
\text { Zambia, } \\
\text { Africa, Libya }\end{array}$ & 6849 & $\begin{array}{l}(15)(33)(63)(57) \\
(67)(47)(48) \\
(27)(24)(61)(23) \\
(20)(50)\end{array}$ & $\begin{array}{l}48.19 \\
64.61]\end{array} \quad[31.77$, & $\begin{array}{l}\mathrm{Tau}^{2}=815.66 ; \\
\mathrm{Chi}^{2}=1068.09, \mathrm{df} \\
=11 \quad(\mathrm{P} \quad< \\
0.00001) ; \mathrm{I}^{2}= \\
99 \%\end{array}$ & $\begin{array}{l}Z=5.75(P< \\
0.00001)\end{array}$ & $\begin{array}{l}\text { Random } \\
\text { Effect }\end{array}$ \\
\hline
\end{tabular}

Table 3. Awareness and attitude toward HBV among African HCWs

\begin{tabular}{|c|c|c|c|c|c|c|c|}
\hline Question & Countries & $\begin{array}{l}\text { Total } \\
\text { sample size }\end{array}$ & References & Pooled prevalence & Heterogeneity & $\begin{array}{l}\text { Test for } \\
\text { overall effect }\end{array}$ & $\begin{array}{l}\text { Type } \\
\text { effect }\end{array}$ \\
\hline $\begin{array}{l}\text { Do you hear about } \\
\text { hepatitis B viral } \\
\text { infection? }\end{array}$ & $\begin{array}{l}\text { Tanzania, Ghana, } \\
\text { Nigeria, Cameroon, } \\
\text { Sudan }\end{array}$ & 1259 & $\begin{array}{l}(51)(72)(59)(48) \\
(58)(76)\end{array}$ & $\begin{array}{l}92.46 \\
97.24]\end{array} \quad[87.67$, & $\begin{array}{l}\mathrm{Tau}^{2}=29.68 ; \mathrm{Chi}^{2} \\
=49.05, \mathrm{df}=5(\mathrm{P} \\
<0.00001) ; \mathrm{I}^{2}= \\
90 \%\end{array}$ & $\begin{array}{l}\mathrm{Z}=37.88(\mathrm{P}< \\
0.00001)\end{array}$ & $\begin{array}{l}\text { Random } \\
\text { Effect }\end{array}$ \\
\hline $\begin{array}{l}\text { Does Your job put } \\
\text { you at greater risk of } \\
\text { HBV infection? }\end{array}$ & $\begin{array}{ll}\text { Tanzania, } & \text { Nigeria, } \\
\text { Ethiopia, } & \text { Ghana, } \\
\text { Sierra } & \text { Leone, } \\
\text { Cameroon } & \end{array}$ & 2554 & $\begin{array}{l}(51)(40)(53)(69) \\
(52)(46)(59)(35) \\
(48)(24)(17)\end{array}$ & $\begin{array}{l}93.24 \\
95.79]\end{array}$ & $\begin{array}{l}\mathrm{Tau}^{2}=14.70 ; \mathrm{Chi}^{2} \\
=98.26, \mathrm{df}=10(\mathrm{P} \\
<0.00001) ; \mathrm{I}^{2}= \\
90 \%\end{array}$ & $\begin{array}{l}\mathrm{Z}=71.75(\mathrm{P}< \\
0.00001)\end{array}$ & $\begin{array}{l}\text { Random } \\
\text { Effect }\end{array}$ \\
\hline $\begin{array}{l}\text { Is the Hepatitis B } \\
\text { vaccine effective in } \\
\text { preventing HBV }\end{array}$ & $\begin{array}{l}\text { Tanzania, Ethiopia, } \\
\text { Senegal, Nigeria }\end{array}$ & 1079 & $\begin{array}{l}(51)(15)(65)(75) \\
(68)\end{array}$ & $\begin{array}{l}85.49 \\
95.65]\end{array}$ & $\begin{array}{l}\mathrm{Tau}^{2}=127.92 ; \\
\mathrm{Chi}^{2}=110.16, \mathrm{df}= \\
4(\mathrm{P}<0.00001) ; \mathrm{I}^{2}\end{array}$ & $\begin{array}{l}\mathrm{Z}=16.49(\mathrm{P}< \\
0.00001)\end{array}$ & $\begin{array}{l}\text { Random } \\
\text { Effect }\end{array}$ \\
\hline
\end{tabular}




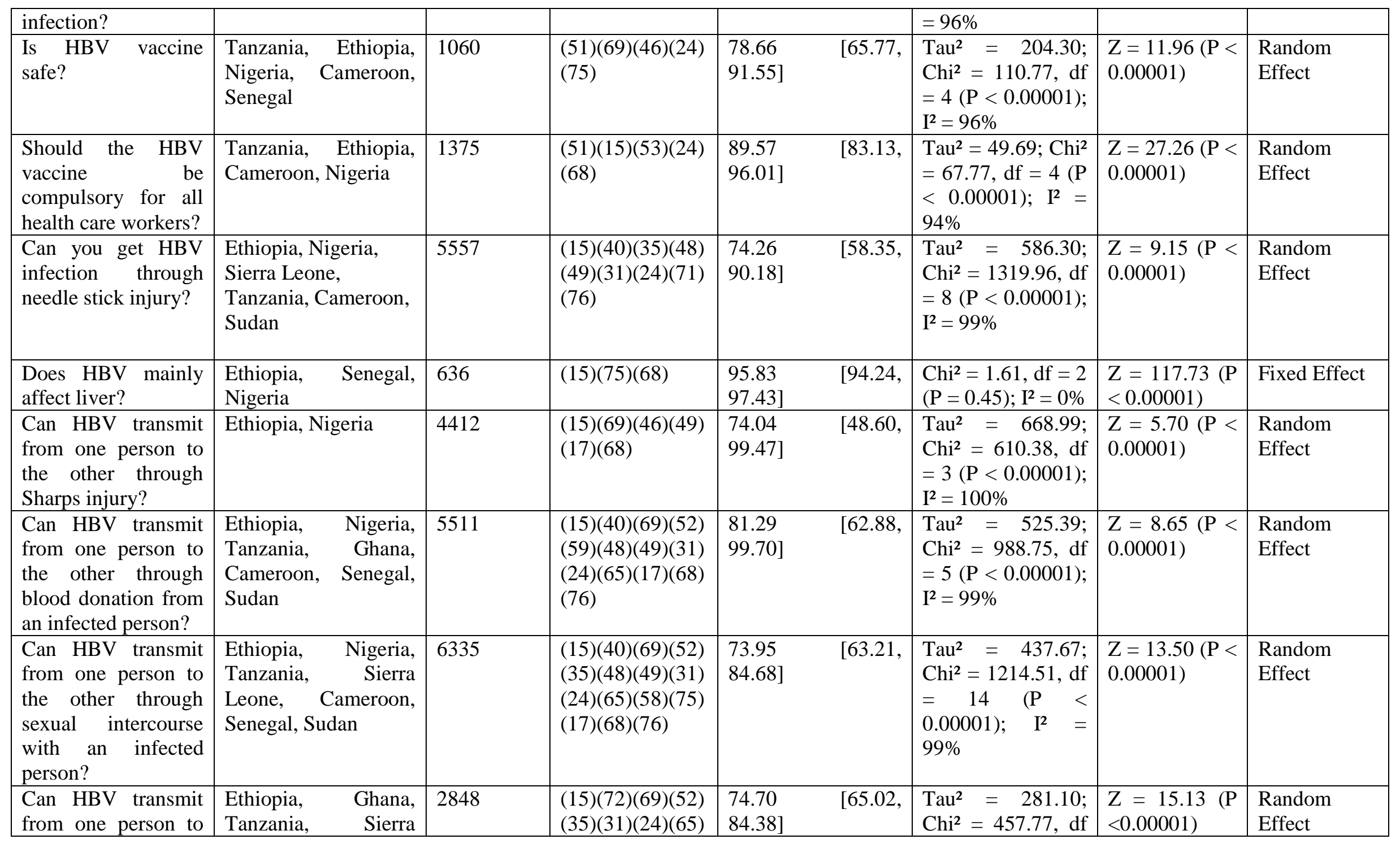




\begin{tabular}{|c|c|c|c|c|c|c|c|}
\hline $\begin{array}{l}\text { the other during } \\
\text { pregnancy (from the } \\
\text { mother to her child)? }\end{array}$ & $\begin{array}{l}\text { Leone, Cameroon, } \\
\text { Senegal, Sudan }\end{array}$ & & $(58)(75)(17)(76)$ & & $\begin{array}{lll}=\quad 11 & (\mathrm{P} & < \\
0.00001) ; & \mathrm{I}^{2}= \\
98 \% & & \end{array}$ & & \\
\hline $\begin{array}{l}\text { Can HBV transmit } \\
\text { from one person to } \\
\text { the other through the } \\
\text { Fecal oral route? }\end{array}$ & $\begin{array}{l}\text { Ethiopia, Tanzania, } \\
\text { Cameroon }\end{array}$ & 1142 & $(15)(31)(24)(17)$ & $\begin{array}{l}30.60 \quad[22.56, \\
38.64]\end{array}$ & $\begin{array}{l}\mathrm{Tau}^{2}=39.57 ; \mathrm{Chi}^{2} \\
=7.54, \mathrm{df}=3(\mathrm{P}= \\
0.06) ; \mathrm{I}^{2}=60 \%\end{array}$ & $\begin{array}{l}Z=7.46(\mathrm{P}< \\
0.00001)\end{array}$ & $\begin{array}{l}\text { Random } \\
\text { Effect }\end{array}$ \\
\hline $\begin{array}{l}\text { Can HBV transmit } \\
\text { from one person to } \\
\text { the other through the } \\
\text { polluted water? }\end{array}$ & $\begin{array}{l}\text { Ethiopia, Nigeria, } \\
\text { Senegal }\end{array}$ & 3589 & $(15)(49)(75)$ & $30.73[-0.80,62.26]$ & $\begin{array}{l}\mathrm{Tau}^{2}=756.26 ; \\
\mathrm{Chi}^{2}=96.05, \mathrm{df}= \\
2(\mathrm{P}<0.00001) ; \mathrm{I}^{2} \\
=98 \%\end{array}$ & $\begin{array}{l}Z=1.91(P= \\
0.06)\end{array}$ & $\begin{array}{l}\text { Random } \\
\text { Effect }\end{array}$ \\
\hline $\begin{array}{l}\text { can Hepatitis B } \\
\text { vaccine be given as } \\
\text { post-exposure } \\
\text { prophylaxis? }\end{array}$ & $\begin{array}{l}\text { Ethiopia, Nigeria, } \\
\text { Sudan }\end{array}$ & 772 & $(15)(40)(68)(76)$ & {$[38.63$} & $\begin{array}{l}\mathrm{Tau}^{2}=46.25 ; \mathrm{Chi}^{2} \\
=7.72, \mathrm{df}=3(\mathrm{P}= \\
0.05) ; \mathrm{I}^{2}=61 \%\end{array}$ & $\begin{array}{l}Z=10.73(P< \\
0.00001)\end{array}$ & $\begin{array}{l}\text { Random } \\
\text { Effect }\end{array}$ \\
\hline $\begin{array}{l}\text { Is there an effective } \\
\text { vaccine to prevent } \\
\text { hepatitis } \\
\text { infection? }\end{array}$ & $\begin{array}{l}\text { Ethiopia, Nigeria, } \\
\text { Tanzania, Cameroon, } \\
\text { Sudan }\end{array}$ & 1410 & $\begin{array}{l}(15)(46)(48)(31) \\
(24)(76)\end{array}$ & $\begin{array}{l}90.53 \quad[87.63, \\
93.43] \quad\end{array}$ & $\begin{array}{l}\mathrm{Tau}^{2}=6.53 ; \mathrm{Chi}^{2} \\
=11.20, \mathrm{df}=4(\mathrm{P} \\
=0.02) ; \mathrm{I}^{2}=64 \%\end{array}$ & $\begin{array}{l}Z=61.14(P< \\
0.00001)\end{array}$ & $\begin{array}{l}\text { Random } \\
\text { Effect }\end{array}$ \\
\hline $\begin{array}{l}\text { Can you get HBV } \\
\text { infection through } \\
\text { mucous membrane } \\
\text { contact with blood? }\end{array}$ & $\begin{array}{l}\text { Ethiopia, Nigeria, } \\
\text { Tanzania, Cameroon, } \\
\text { Senegal }\end{array}$ & 1123 & $\begin{array}{l}(69)(46)(31)(24) \\
(75)\end{array}$ & $\begin{array}{l}71.40[63.45, \\
79.36]\end{array}$ & $\begin{array}{l}\mathrm{Tau}^{2}=63.23 ; \mathrm{Chi}^{2} \\
=24.46, \mathrm{df}=4(\mathrm{P} \\
<0.0001) ; \mathrm{I}^{2}= \\
84 \%\end{array}$ & $\begin{array}{l}Z=17.59(P< \\
0.00001)\end{array}$ & $\begin{array}{l}\text { Random } \\
\text { Effect }\end{array}$ \\
\hline $\begin{array}{l}\text { Does HBV cause } \\
\text { liver cancer? }\end{array}$ & $\begin{array}{l}\text { Ethiopia, } \quad \text { Sierra } \\
\text { Leone, } \\
\text { Senegal }\end{array}$ & 1127 & $\begin{array}{l}(69)(35)(48)(65) \\
(75)\end{array}$ & {$[67.95$} & $\begin{array}{l}\mathrm{Tau}^{2}=157.73 ; \\
\mathrm{Chi}^{2}=142.49, \mathrm{df} \\
=4(\mathrm{P}<0.00001) \\
\mathrm{I}^{2}=97 \%\end{array}$ & $\begin{array}{l}Z=13.63(P< \\
0.00001)\end{array}$ & $\begin{array}{l}\text { Random } \\
\text { Effect }\end{array}$ \\
\hline $\begin{array}{lrr}\text { Could HBV } & \text { be } \\
\text { transmitted through } \\
\text { contact of } & \text { the } \\
\text { broken skin } & \text { with } \\
\text { infected } & \text { body } \\
\text { fluids? } & & \\
\end{array}$ & $\begin{array}{l}\text { Nigeria, Tanzania, } \\
\text { Cameroon, Ethiopia }\end{array}$ & 1357 & $\begin{array}{l}(46)(31)(24)(58) \\
(17)\end{array}$ & $\begin{array}{l}84.21 \quad[76.22, \\
92.19] \quad\end{array}$ & $\begin{array}{l}\mathrm{Tau}^{2}=75.22 ; \mathrm{Chi}^{2} \\
=64.81, \mathrm{df}=4(\mathrm{P} \\
<0.00001) ; \mathrm{I}^{2}= \\
94 \%\end{array}$ & $\begin{array}{l}Z=20.67(P< \\
0.00001)\end{array}$ & $\begin{array}{l}\text { Random } \\
\text { Effect }\end{array}$ \\
\hline
\end{tabular}




\begin{tabular}{|c|c|c|c|c|c|c|c|}
\hline $\begin{array}{l}\text { Can HBV } \\
\text { immunoglobulin } \\
\text { prevent infection } \\
\text { after exposure? }\end{array}$ & $\begin{array}{l}\text { Tanzania, Cameroon, } \\
\text { Senegal }\end{array}$ & 629 & $(31)(24)(75)$ & $\begin{array}{l}39.51 \quad[21.39, \\
57.64]\end{array}$ & $\begin{array}{l}\mathrm{Tau}^{2}=212.36 \\
\mathrm{Chi}^{2}=12.64, \mathrm{df}= \\
2(\mathrm{P}=0.002) ; \mathrm{I}^{2}= \\
84 \%\end{array}$ & $\begin{array}{l}\mathrm{Z}=4.27(\mathrm{P}< \\
0.0001)\end{array}$ & $\begin{array}{l}\text { Random } \\
\text { Effect }\end{array}$ \\
\hline $\begin{array}{l}\text { Is your reason for } \\
\text { being unvaccinated } \\
\text { unavailability of the } \\
\text { vaccine at your } \\
\text { working place? }\end{array}$ & $\begin{array}{l}\text { Tanzania, Ethiopia, } \\
\text { Kenya, Ghana, } \\
\text { Nigeria }\end{array}$ & 1240 & $\begin{array}{l}(51)(53)(70)(33) \\
(59)(63)(48)(49) \\
(68)\end{array}$ & $\begin{array}{l}47.67[30.57, \\
64.77]\end{array}$ & $\begin{array}{l}\mathrm{Tau}^{2}=636.05 ; \\
\mathrm{Chi}^{2}=132.56, \mathrm{df} \\
=8(\mathrm{P}<0.00001) \\
\mathrm{I}^{2}=94 \%\end{array}$ & $\begin{array}{l}\mathrm{Z}=5.46(\mathrm{P}< \\
0.00001)\end{array}$ & $\begin{array}{l}\text { Random } \\
\text { Effect }\end{array}$ \\
\hline $\begin{array}{l}\text { Is your reason for } \\
\text { being unvaccinated, } \\
\text { the high cost of the } \\
\text { vaccine for private } \\
\text { access? }\end{array}$ & $\begin{array}{l}\text { Ethiopia, Tanzania, } \\
\text { Nigeria, Cameroon }\end{array}$ & 897 & $\begin{array}{l}(53)(70)(52)(57) \\
(48)(24)(68)\end{array}$ & $\begin{array}{l}21.88[11.18, \\
32.57]\end{array}$ & $\begin{array}{l}\mathrm{Tau}^{2}=128.02 ; \\
\mathrm{Chi}^{2}=16.50, \mathrm{df}= \\
6(\mathrm{P}=0.01) ; \mathrm{I}^{2}= \\
64 \%\end{array}$ & $\begin{array}{l}\mathrm{Z}=4.01(\mathrm{P}< \\
0.0001)\end{array}$ & $\begin{array}{l}\text { Random } \\
\text { Effect }\end{array}$ \\
\hline $\begin{array}{l}\text { Is your reason for } \\
\text { being unvaccinated } \\
\text { the Lack of } \\
\text { information about } \\
\text { the vaccine? }\end{array}$ & Ethiopia, Nigeria & 384 & $(70)(46)(68)$ & $15.99[6.83,25.15]$ & $\begin{array}{l}\mathrm{Chi}^{2}=1.49, \mathrm{df}=2 \\
(\mathrm{P}=0.47) ; \mathrm{I}^{2}=0 \%\end{array}$ & $\begin{array}{l}\mathrm{Z}=3.42(\mathrm{P}= \\
0.0006)\end{array}$ & $\begin{array}{l}\text { Random } \\
\text { Effect }\end{array}$ \\
\hline $\begin{array}{l}\text { Is your reason for } \\
\text { being unvaccinated } \\
\text { the vaccine } \\
\text { unnecessary? }\end{array}$ & $\begin{array}{l}\text { Tanzania, Kenya, } \\
\text { Nigeria }\end{array}$ & 180 & $(52)(63)(48)$ & $21.45[8.76,34.15]$ & $\begin{array}{l}\mathrm{Chi}^{2}=4.17, \mathrm{df}=2 \\
(\mathrm{P}=0.12) ; \mathrm{I}^{2}= \\
52 \%\end{array}$ & $\begin{array}{l}\mathrm{Z}=3.31(\mathrm{P}= \\
0.0009)\end{array}$ & $\begin{array}{l}\text { Random } \\
\text { Effect }\end{array}$ \\
\hline $\begin{array}{l}\text { Is your reason for } \\
\text { being unvaccinated, } \\
\text { not mentioned above } \\
\text { (other)? }\end{array}$ & $\begin{array}{l}\text { Ethiopia, Tanzania, } \\
\text { Ghana, Nigeria }\end{array}$ & 924 & $\begin{array}{l}(53)(70)(52)(59) \\
(49)\end{array}$ & $16.97[2.01,31.92]$ & $\begin{array}{l}\mathrm{Tau}^{2}=230.95 \\
\mathrm{Chi}^{2}=22.30, \mathrm{df}= \\
4(\mathrm{P}=0.0002) ; \mathrm{I}^{2} \\
=82 \%\end{array}$ & $\begin{array}{l}\mathrm{Z}=2.22(\mathrm{P}= \\
0.03)\end{array}$ & $\begin{array}{l}\text { Random } \\
\text { Effect }\end{array}$ \\
\hline $\begin{array}{l}\text { Are the three doses } \\
\text { of HBV vaccine } \\
\text { required for } \\
\text { complete protection? }\end{array}$ & $\begin{array}{l}\text { Nigeria, Tanzania, } \\
\text { Cameroon }\end{array}$ & 676 & $(40)(31)(24)$ & {$[61.09$} & $\begin{array}{l}\mathrm{Tau}^{2}=111.78 \\
\mathrm{Chi}^{2}=18.34, \mathrm{df}= \\
2(\mathrm{P}=0.0001) ; \mathrm{I}^{2} \\
=89 \%\end{array}$ & $\begin{array}{l}\mathrm{Z}=11.37(\mathrm{P}< \\
0.00001)\end{array}$ & $\begin{array}{l}\text { Random } \\
\text { Effect }\end{array}$ \\
\hline
\end{tabular}


Table 4. Awareness and attitude toward HIV among African HCWs

\begin{tabular}{|c|c|c|c|c|c|c|c|}
\hline Questions & Countries & $\begin{array}{l}\text { Total } \\
\text { sample size }\end{array}$ & References & Pooled prevalence & Heterogeneity & $\begin{array}{l}\text { Test for } \\
\text { overall effect }\end{array}$ & $\begin{array}{l}\text { Type } \\
\text { effect }\end{array}$ \\
\hline $\begin{array}{l}\text { Ever Heard about } \\
\text { HIV-Post Exposure } \\
\text { Prophylaxis (PEP)? }\end{array}$ & $\begin{array}{l}\text { Nigeria, Cameroon, } \\
\text { Tanzania, Ethiopia }\end{array}$ & 1013 & $\begin{array}{l}(83)(87)(80)(84) \\
(55)\end{array}$ & $\begin{array}{l}90.62 \\
96.69]\end{array} \quad[84.55$, & $\begin{array}{l}\mathrm{Tau}^{2}=41.63 ; \mathrm{Chi}^{2} \\
=93.99, \mathrm{df}=4(\mathrm{P} \\
<0.00001) ; \mathrm{I}^{2}= \\
96 \%\end{array}$ & $\begin{array}{l}\mathrm{Z}=29.25(\mathrm{P}< \\
0.00001)\end{array}$ & $\begin{array}{l}\text { Random } \\
\text { Effect }\end{array}$ \\
\hline $\begin{array}{lr}\text { Are } & \text { percutaneous } \\
\text { injuries } & \text { considered } \\
\text { high-risk } & \text { exposures } \\
\text { for HIV transmission? }\end{array}$ & Nigeria, Ethiopia & 1334 & $(83)(18)(71)(55)$ & $\begin{array}{l}72.08 \quad[47.80, \\
96.35] \quad\end{array}$ & $\begin{array}{l}\mathrm{Tau}^{2}=602.09 ; \\
\mathrm{Chi}^{2}=251.54, \mathrm{df} \\
=3(\mathrm{P}<0.00001) ; \\
\mathrm{I}^{2}=99 \%\end{array}$ & $\begin{array}{l}\mathrm{Z}=5.82(\mathrm{P}< \\
0.00001)\end{array}$ & $\begin{array}{l}\text { Random } \\
\text { Effect }\end{array}$ \\
\hline $\begin{array}{l}\text { Is HIV can transmit } \\
\text { through Breast milk? }\end{array}$ & Nigeria, Cameroon & 360 & $(83)(87)(86)$ & $\begin{array}{l}86.61 \quad[82.83, \\
90.39]\end{array}$ & $\begin{array}{l}\mathrm{Chi}^{2}=1.84, \mathrm{df}=2 \\
(\mathrm{P}=0.40) ; \mathrm{I}^{2}=0 \%\end{array}$ & $\begin{array}{l}\mathrm{Z}=44.91(\mathrm{P}< \\
0.00001)\end{array}$ & Fixed Effect \\
\hline $\begin{array}{l}\text { Is HIV can transmit } \\
\text { through Saliva? }\end{array}$ & Nigeria, Cameroon & 357 & $(83)(87)(86)$ & $20.54[5.37,35.71]$ & $\begin{array}{l}\mathrm{Tau}^{2}=110.41 \\
\mathrm{Chi}^{2}=5.20, \mathrm{df}=2 \\
(\mathrm{P}=0.07) ; \mathrm{I}^{2}= \\
62 \%\end{array}$ & $\begin{array}{l}\mathrm{Z}=2.65(\mathrm{P}= \\
0.008)\end{array}$ & $\begin{array}{l}\text { Random } \\
\text { Effect }\end{array}$ \\
\hline $\begin{array}{l}\text { Do you consider } \\
\text { yourself to be at risk } \\
\text { for HIV acquisition at } \\
\text { your workplace? }\end{array}$ & $\begin{array}{l}\text { Nigeria, Cameroon, } \\
\text { Ethiopia, Tanzania }\end{array}$ & 1176 & $\begin{array}{l}(83)(87)(18)(79) \\
(55)\end{array}$ & {$[58.13$} & $\begin{array}{l}\mathrm{Tau}^{2}=360.13 ; \\
\mathrm{Chi}^{2}=244.88, \mathrm{df} \\
=4(\mathrm{P}<0.00001) \\
\mathrm{I}^{2}=98 \%\end{array}$ & $\begin{array}{l}\mathrm{Z}=8.70(\mathrm{P}< \\
0.00001)\end{array}$ & $\begin{array}{l}\text { Random } \\
\text { Effect }\end{array}$ \\
\hline $\begin{array}{l}\text { Is a wash thoroughly } \\
\text { with soap and water } \\
\text { the initial first-aid } \\
\text { measure to institute } \\
\text { following needle stick } \\
\text { injury? }\end{array}$ & Nigeria, Cameroon & 407 & $(83)(87)(84)$ & $\begin{array}{l}52.17 \\
109.23]\end{array}$ & $\begin{array}{l}\mathrm{Tau}^{2}=2501.11 ; \\
\mathrm{Chi}^{2}=159.31, \mathrm{df} \\
=2(\mathrm{P}<0.00001) \\
\mathrm{I}^{2}=99 \%\end{array}$ & $\begin{array}{l}\mathrm{Z}=1.79(\mathrm{P}= \\
0.07)\end{array}$ & $\begin{array}{l}\text { Random } \\
\text { Effect }\end{array}$ \\
\hline $\begin{array}{l}\text { Ever had training on } \\
\text { PEP? }\end{array}$ & $\begin{array}{l}\text { Cameroon, } \\
\text { Ethiopia, Tanzania }\end{array}$ & 494 & $(87)(18)(80)$ & {$[24.09$} & $\begin{array}{l}\mathrm{Tau}^{2}=496.76 ; \\
\mathrm{Chi}^{2}=34.68, \mathrm{df}= \\
2(\mathrm{P}<0.00001) ; \mathrm{I}^{2} \\
=94 \%\end{array}$ & $\begin{array}{l}\mathrm{Z}=3.75(\mathrm{P}= \\
0.0002)\end{array}$ & $\begin{array}{l}\text { Random } \\
\text { Effect }\end{array}$ \\
\hline What is the duration of & Nigeria, Cameroon, & 559 & $(83)(87)(55)$ & {$[50.73$,} & $\mathrm{Tau}^{2}=266.43$ & $Z=7.06(P$ & Random \\
\hline
\end{tabular}




\begin{tabular}{|c|c|c|c|c|c|c|c|}
\hline HIV-PEP: 4 weeks? & Ethiopia & & & 89.72] & $\begin{array}{l}\mathrm{Chi}^{2}=48.45, \mathrm{df}= \\
2(\mathrm{P}<0.00001) ; \mathrm{I}^{2} \\
=96 \%\end{array}$ & $<0.00001)$ & Effect \\
\hline $\begin{array}{l}\text { Should HIV-PEP be } \\
\text { administered for } \\
\text { needle stick injury? }\end{array}$ & $\begin{array}{l}\text { Nigeria, Cameroon, } \\
\text { Ethiopia }\end{array}$ & 227 & $(83)(87)(55)$ & $38.03[1.34,74.73]$ & $\begin{array}{l}\mathrm{Tau}^{2}=962.82 ; \\
\mathrm{Chi}^{2}=26.18, \mathrm{df}= \\
2(\mathrm{P}<0.00001) ; \mathrm{I}^{2} \\
=92 \%\end{array}$ & $\begin{array}{l}\mathrm{Z}=2.03(\mathrm{P}= \\
0.04)\end{array}$ & $\begin{array}{l}\text { Random } \\
\text { Effect }\end{array}$ \\
\hline $\begin{array}{l}\text { How soon after needle } \\
\text { stick injury should } \\
\text { PEP be commenced: } \\
\text { within } 1 \text { hour }\end{array}$ & $\begin{array}{l}\text { Nigeria, Cameroon, } \\
\text { Ethiopia }\end{array}$ & 555 & $(83)(87)(55)$ & $\begin{array}{l}84.95 \\
94.47]\end{array}$ & $\begin{array}{l}\mathrm{Tau}^{2}=57.91 ; \mathrm{Chi}^{2} \\
=18.93, \mathrm{df}=2(\mathrm{P} \\
<0.0001) ; \mathrm{I}^{2}= \\
89 \%\end{array}$ & $\begin{array}{l}Z=17.49(P< \\
0.00001)\end{array}$ & $\begin{array}{l}\text { Random } \\
\text { Effect }\end{array}$ \\
\hline $\begin{array}{l}\text { How soon after needle } \\
\text { stick injury should } \\
\text { PEP be commenced: } \\
\text { after } 72 \text { hours }\end{array}$ & $\begin{array}{l}\text { Nigeria, Cameroon, } \\
\text { Ethiopia }\end{array}$ & 555 & $(83)(87)(55)$ & $10.52[-2.88,23.92]$ & $\begin{array}{l}\mathrm{Tau}^{2}=84.50 ; \mathrm{Chi}^{2} \\
=5.08, \mathrm{df}=2(\mathrm{P}= \\
0.08) ; \mathrm{I}^{2}=61 \%\end{array}$ & $\begin{array}{l}\mathrm{Z}=1.54(\mathrm{P}= \\
0.12)\end{array}$ & $\begin{array}{l}\text { Random } \\
\text { Effect }\end{array}$ \\
\hline
\end{tabular}

Table 5. Awareness and attitude toward TB among African HCWs.

\begin{tabular}{|c|c|c|c|c|c|c|c|}
\hline Questions & Countries & $\begin{array}{l}\text { Total } \\
\text { sample size }\end{array}$ & References & Pooled prevalence & Heterogeneity & $\begin{array}{l}\text { Test for } \\
\text { overall effect }\end{array}$ & $\begin{array}{l}\text { Type } \\
\text { effect }\end{array}$ \\
\hline $\begin{array}{l}\text { Would you be screened } \\
\text { suspicious TB patients in } \\
\text { waiting areas? }\end{array}$ & $\begin{array}{l}\text { South Africa, } \\
\text { Ethiopia }\end{array}$ & 701 & $(97)(91)(54)$ & $\begin{array}{l}37.77 \quad[12.34, \\
63.19]\end{array}$ & $\begin{array}{l}\mathrm{Tau}^{2}=471.49 ; \mathrm{Chi}^{2} \\
=36.27, \mathrm{df}=2(\mathrm{P}< \\
0.00001) ; \mathrm{I}^{2}=94 \%\end{array}$ & $\begin{array}{l}\mathrm{Z}=2.91(\mathrm{P}= \\
0.004)\end{array}$ & $\begin{array}{l}\text { Random } \\
\text { Effect }\end{array}$ \\
\hline $\begin{array}{l}\text { Would you prioritize TB } \\
\text { suspects for prompt } \\
\text { service? }\end{array}$ & $\begin{array}{l}\text { South Africa, } \\
\text { Ethiopia }\end{array}$ & 638 & $(97)(91)(99)$ & $47.21[0.79,93.64]$ & $\begin{array}{l}\mathrm{Tau}^{2}=1653.02 ; \\
\mathrm{Chi}^{2}=165.29, \mathrm{df}= \\
2(\mathrm{P}<0.00001) ; \mathrm{I}^{2} \\
=99 \%\end{array}$ & $\begin{array}{l}\mathrm{Z}=1.99(\mathrm{P}= \\
0.05)\end{array}$ & $\begin{array}{l}\text { Random } \\
\text { Effect }\end{array}$ \\
\hline $\begin{array}{l}\text { Do you isolate the } \\
\text { patients, use of separate } \\
\text { TB ward? }\end{array}$ & $\begin{array}{l}\text { South Africa, } \\
\text { Ethiopia }\end{array}$ & 588 & $(97)(54)(99)$ & {$[24.38$} & $\begin{array}{l}\mathrm{Tau}^{2}=814.66 ; \mathrm{Chi}^{2} \\
=88.85, \mathrm{df}=2(\mathrm{P}< \\
0.00001) ; \mathrm{I}^{2}=98 \%\end{array}$ & $\begin{array}{l}Z=3.42(P= \\
0.0006)\end{array}$ & $\begin{array}{l}\text { Random } \\
\text { Effect }\end{array}$ \\
\hline $\begin{array}{llr}\text { Would } & \text { you } & \text { open } \\
\text { windows } & \text { for } & \text { ventilation }\end{array}$ & $\begin{array}{l}\text { South Africa, } \\
\text { Ethiopia }\end{array}$ & 1481 & $\begin{array}{l}(97)(91)(54)(99) \\
(90)\end{array}$ & $\begin{array}{l}75.40 \\
86.22]\end{array}$ & $\begin{array}{l}\mathrm{Tau}^{2}=141.28 ; \mathrm{Chi}^{2} \\
=286.68, \mathrm{df}=4(\mathrm{P}\end{array}$ & $\begin{array}{l}\mathrm{Z}=13.66(\mathrm{P} \\
<0.00001)\end{array}$ & $\begin{array}{l}\text { Random } \\
\text { Effect }\end{array}$ \\
\hline
\end{tabular}




\begin{tabular}{|c|c|c|c|c|c|c|c|c|}
\hline and sunlight? & & & & & & $\begin{array}{l}<0.00001) ; \mathrm{I}^{2}= \\
99 \%\end{array}$ & & \\
\hline $\begin{array}{l}\text { Do you use a mask when } \\
\text { approaching } \\
\text { suspected patients? }\end{array}$ & $\begin{array}{l}\text { Ethiopia, South } \\
\text { Africa }\end{array}$ & 1266 & $(91)(54)(90)(96)$ & $\begin{array}{l}49.08 \\
81.83]\end{array}$ & {$[16.34$} & $\begin{array}{l}\mathrm{Tau}^{2}=1097.37 ; \\
\mathrm{Chi}^{2}=231.82, \mathrm{df}= \\
3(\mathrm{P}<0.00001) ; \mathrm{I}^{2} \\
=99 \%\end{array}$ & $\begin{array}{l}Z=2.94(P= \\
0.003)\end{array}$ & $\begin{array}{l}\text { Random } \\
\text { Effect }\end{array}$ \\
\hline $\begin{array}{l}\text { Does TB transmit by } \\
\text { airborne? }\end{array}$ & $\begin{array}{l}\text { South Africa, } \\
\text { Nigeria, } \\
\text { Ethiopia, } \\
\text { Uganda }\end{array}$ & 1239 & $\begin{array}{l}(97)(95)(92)(54) \\
(100)\end{array}$ & $\begin{array}{l}96.12 \\
98.47]\end{array}$ & {$[93.77$} & $\begin{array}{l}\mathrm{Tau}^{2}=4.66 ; \mathrm{Chi}^{2}= \\
21.30, \mathrm{df}=4(\mathrm{P}= \\
0.0003) ; \mathrm{I}^{2}=81 \%\end{array}$ & $\begin{array}{l}\mathrm{Z}=80.28(\mathrm{P} \\
<0.00001)\end{array}$ & $\begin{array}{l}\text { Random } \\
\text { Effect }\end{array}$ \\
\hline $\begin{array}{l}\text { How are you concerned } \\
\text { about getting TB at your } \\
\text { work? }\end{array}$ & $\begin{array}{l}\text { South Africa, } \\
\text { Ethiopia, } \\
\text { Uganda }\end{array}$ & 990 & $(99)(54)(100)$ & $\begin{array}{l}84.47 \\
97.47]\end{array}$ & {$[71.47$} & $\begin{array}{l}\mathrm{Tau}^{2}=125.77 ; \mathrm{Chi}^{2} \\
=53.48, \mathrm{df}=2(\mathrm{P}< \\
0.00001) ; \mathrm{I}^{2}=96 \%\end{array}$ & $\begin{array}{l}Z=12.74(P \\
<0.00001)\end{array}$ & $\begin{array}{l}\text { Random } \\
\text { Effect }\end{array}$ \\
\hline $\begin{array}{l}\text { Does opening a window } \\
\text { considered an effective } \\
\text { TB infection control } \\
\text { measure? }\end{array}$ & $\begin{array}{l}\text { Nigeria, South } \\
\text { Africa, Ethiopia }\end{array}$ & 713 & $(99)(95)(91)$ & $\begin{array}{l}85.76 \\
98.32]\end{array}$ & {$[73.19$} & $\begin{array}{l}\mathrm{Tau}^{2}=116.90 ; \mathrm{Chi}^{2} \\
=63.96, \mathrm{df}=2(\mathrm{P}< \\
0.00001) ; \mathrm{I}^{2}=97 \%\end{array}$ & $\begin{array}{l}Z=13.38(P \\
<0.00001)\end{array}$ & $\begin{array}{l}\text { Random } \\
\text { Effect }\end{array}$ \\
\hline $\begin{array}{l}\text { Do you agree that } \\
\text { surgical masks do not } \\
\text { protect the wearer against } \\
\text { TB infection? }\end{array}$ & $\begin{array}{l}\text { South Africa, } \\
\text { Uganda, } \\
\text { Ethiopia }\end{array}$ & 1316 & $(99)(100)(90)$ & $\begin{array}{l}35.28 \\
39.65]\end{array}$ & {$[30.90$} & $\begin{array}{l}\mathrm{Chi}^{2}=3.34, \mathrm{df}=2 \\
(\mathrm{P}=0.19) ; \mathrm{I}^{2}= \\
40 \%\end{array}$ & $\begin{array}{l}Z=15.79(P \\
<0.00001)\end{array}$ & Fixed Effect \\
\hline $\begin{array}{l}\text { Doses HIV consider as a } \\
\text { predisposition to } \\
\text { contracting TB? }\end{array}$ & $\begin{array}{l}\text { South Africa, } \\
\text { Ethiopia, } \\
\text { Nigeria, Uganda }\end{array}$ & 1547 & $\begin{array}{l}(97)(99)(95)(92) \\
(54)(93)(100)\end{array}$ & $\begin{array}{l}77.11 \\
85.74]\end{array}$ & {$[68.48$,} & $\begin{array}{l}\mathrm{Tau}^{2}=123.06 ; \mathrm{Chi}^{2} \\
=293.81, \mathrm{df}=6(\mathrm{P} \\
<\quad 0.00001) ; \mathrm{I}^{2}= \\
98 \%\end{array}$ & $\begin{array}{l}\mathrm{Z}=17.51(\mathrm{P} \\
<0.00001)\end{array}$ & $\begin{array}{l}\text { Random } \\
\text { Effect }\end{array}$ \\
\hline $\begin{array}{l}\text { What is the pulmonary } \\
\text { TB } \\
\text { symptoms: constitutional } \\
\text { cough? }\end{array}$ & $\begin{array}{l}\text { South Africa, } \\
\text { Nigeria, } \\
\text { Ethiopia. }\end{array}$ & 636 & $(97)(99)(95)(92)$ & $\begin{array}{l}91.08 \\
98.02]\end{array}$ & {$[84.14$} & $\begin{array}{l}\mathrm{Tau}^{2}=42.93 ; \mathrm{Chi}^{2} \\
=46.92, \mathrm{df}=3(\mathrm{P}< \\
0.00001) ; \mathrm{I}^{2}=94 \%\end{array}$ & $\begin{array}{l}\mathrm{Z}=25.73(\mathrm{P} \\
<0.00001)\end{array}$ & $\begin{array}{l}\text { Random } \\
\text { Effect }\end{array}$ \\
\hline $\begin{array}{l}\text { What is the pulmonary } \\
\text { TB constitutional } \\
\text { symptoms: Weight loss? }\end{array}$ & $\begin{array}{l}\text { South Africa, } \\
\text { Nigeria, } \\
\text { Ethiopia. }\end{array}$ & 639 & $(97)(99)(95)(92)$ & $\begin{array}{l}85.01 \\
95.47]\end{array}$ & {$[74.54$} & $\begin{array}{l}\mathrm{Tau}^{2}=102.17 ; \mathrm{Chi}^{2} \\
=42.03, \mathrm{df}=3(\mathrm{P}< \\
0.00001) ; \mathrm{I}^{2}=93 \%\end{array}$ & $\begin{array}{l}Z=15.92(P \\
<0.00001)\end{array}$ & $\begin{array}{l}\text { Random } \\
\text { Effect }\end{array}$ \\
\hline What is the pulmonary & South Africa, & 635 & $(97)(99)(95)(92)$ & 76.95 & {$[65.97$,} & $\mathrm{Tau}^{2}=109.03 ; \mathrm{Chi}^{2}$ & $\mathrm{Z}=13.74(\mathrm{P}$ & Random \\
\hline
\end{tabular}




\begin{tabular}{|c|c|c|c|c|c|c|c|}
\hline $\begin{array}{l}\text { TB constitutional } \\
\text { symptoms: Fever? }\end{array}$ & $\begin{array}{l}\text { Nigeria, } \\
\text { Ethiopia }\end{array}$ & & & 87.92] & $\begin{array}{l}=28.68, \mathrm{df}=3(\mathrm{P}< \\
0.00001) ; \mathrm{I}^{2}=90 \%\end{array}$ & $<0.00001)$ & Effect \\
\hline $\begin{array}{l}\text { What is the pulmonary } \\
\text { TB } \\
\text { symptoms: Night sweats? }\end{array}$ & $\begin{array}{l}\text { South Africa, } \\
\text { Nigeria, } \\
\text { Ethiopia }\end{array}$ & 437 & $(97)(95)(92)$ & $\begin{array}{l}86.09 \quad[75.27, \\
96.92]\end{array}$ & $\begin{array}{l}\mathrm{Tau}^{2}=80.20 ; \mathrm{Chi}^{2} \\
=18.93, \mathrm{df}=2(\mathrm{P}< \\
0.0001) ; \mathrm{I}^{2}=89 \%\end{array}$ & $\begin{array}{l}\mathrm{Z}=15.59(\mathrm{P} \\
<0.00001)\end{array}$ & $\begin{array}{l}\text { Random } \\
\text { Effect }\end{array}$ \\
\hline
\end{tabular}

Table 6. Awareness and attitude toward antibiotics among African HCWs.

\begin{tabular}{|c|c|c|c|c|c|c|c|}
\hline Questions & Countries & $\begin{array}{l}\text { Total } \\
\text { sample size }\end{array}$ & References & Pooled prevalence & Heterogeneity & $\begin{array}{l}\text { Test for } \\
\text { overall effect }\end{array}$ & $\begin{array}{l}\text { Type } \\
\text { effect }\end{array}$ \\
\hline $\begin{array}{l}\text { Does widespread or } \\
\text { overuse of antibiotics } \\
\text { promote antimicrobial } \\
\text { resistance (AMR)? }\end{array}$ & $\begin{array}{l}\text { Ethiopia, } \\
\text { Gambia, } \\
\text { Ghanaian }\end{array}$ & 757 & $(101)(102)(103)$ & $\begin{array}{l}77.75 \\
83.52]\end{array} \quad[71.99$, & $\begin{array}{l}\mathrm{Tau}^{2}=15.48 ; \mathrm{Chi}^{2} \\
=5.03, \mathrm{df}=2(\mathrm{P}= \\
0.08) ; \mathrm{I}^{2}=60 \%\end{array}$ & $\begin{array}{l}Z=26.45(P \\
<0.00001)\end{array}$ & $\begin{array}{l}\text { Random } \\
\text { Effect }\end{array}$ \\
\hline $\begin{array}{l}\text { Does patients' poor } \\
\text { adherence to prescribed } \\
\text { antibiotics } \\
\text { AMR? }\end{array}$ & $\begin{array}{l}\text { Ethiopia, Egypt, } \\
\text { Ghanaian }\end{array}$ & 863 & $(101)(104)(103)$ & $47.18[-2.80,97.16]$ & $\begin{array}{l}\mathrm{Tau}^{2}=1929.33 ; \\
\mathrm{Chi}^{2}=218.24, \mathrm{df}= \\
2(\mathrm{P}<0.00001) ; \mathrm{I}^{2} \\
=99 \%\end{array}$ & $\begin{array}{l}\mathrm{Z}=1.85(\mathrm{P}= \\
0.06)\end{array}$ & $\begin{array}{l}\text { Random } \\
\text { Effect }\end{array}$ \\
\hline $\begin{array}{l}\text { As a local factor, does } \\
\text { self-prescription by } \\
\text { patients develop AMR? }\end{array}$ & $\begin{array}{l}\text { Ethiopia, Egypt, } \\
\text { Ghanaian }\end{array}$ & 858 & $(101)(104)(103)$ & $\begin{array}{l}42.00 \\
65.20]\end{array}$ & $\begin{array}{l}\mathrm{Tau}^{2}=398.18 ; \mathrm{Chi}^{2} \\
=39.55, \mathrm{df}=2(\mathrm{P}< \\
0.00001) ; \mathrm{I}^{2}=95 \%\end{array}$ & $\begin{array}{l}\mathrm{Z}=3.55(\mathrm{P}= \\
0.0004)\end{array}$ & $\begin{array}{l}\text { Random } \\
\text { Effect }\end{array}$ \\
\hline
\end{tabular}

Table 7. Awareness and attitude toward infection control among African HCWs.

\begin{tabular}{|c|c|c|c|c|c|c|c|}
\hline Questions & Countries & $\begin{array}{l}\text { Total } \\
\text { sample size }\end{array}$ & References & Pooled prevalence & Heterogeneity & $\begin{array}{l}\text { Test for } \\
\text { overall effect }\end{array}$ & $\begin{array}{l}\text { Type } \\
\text { effect }\end{array}$ \\
\hline $\begin{array}{l}\text { Are you aware of } \\
\text { guidelines/ protocols for } \\
\text { infection control? }\end{array}$ & $\begin{array}{l}\text { Nigeria, } \\
\text { Ethiopia }\end{array}$ & 611 & $(108)(115)(110)$ & $\begin{array}{l}36.56 \\
77.28]\end{array} \quad[-4.15$, & $\begin{array}{l}\mathrm{Tau}^{2}=1249.38 \\
\mathrm{Chi}^{2}=80.34, \mathrm{df}=2 \\
(\mathrm{P}<0.00001) ; \mathrm{I}^{2}= \\
98 \%\end{array}$ & $\begin{array}{l}\mathrm{Z}=1.76(\mathrm{P}= \\
0.08)\end{array}$ & $\begin{array}{l}\text { Random } \\
\text { Effect }\end{array}$ \\
\hline you attended & Nigeria, & 2605 & $(108)(114)(71)($ & {$[32.20$,} & $\mathrm{Tau}^{2}=304.84 ; \mathrm{Chi}^{2}$ & $Z=6.96(P$ & Random \\
\hline
\end{tabular}




\begin{tabular}{|c|c|c|c|c|c|c|c|}
\hline $\begin{array}{l}\text { training program on } \\
\text { infection control? }\end{array}$ & $\begin{array}{l}\text { Ethiopia, Sierra } \\
\text { Leone }\end{array}$ & & $\begin{array}{l}109)(115)(110)( \\
119)(19)(22)\end{array}$ & $57.45]$ & $\begin{array}{l}=128.86, \mathrm{df}=7(\mathrm{P}< \\
0.00001) ; \mathrm{I}^{2}=95 \%\end{array}$ & $<0.00001)$ & Effect \\
\hline $\begin{array}{lcr}\text { Do you have } & \text { enough } \\
\text { gloves } & \text { in } & \text { your } \\
\text { workplace? } & & \end{array}$ & $\begin{array}{l}\text { Egypt, Nigeria, } \\
\text { Uganda }\end{array}$ & 683 & $(74)(109)(117)$ & $\begin{array}{l}57.49 \quad[21.76, \\
93.21] \quad\end{array}$ & $\begin{array}{l}\mathrm{Tau}^{2}=976.96 ; \mathrm{Chi}^{2} \\
=146.05, \mathrm{df}=2(\mathrm{P}< \\
0.00001) ; \mathrm{I}^{2}=99 \%\end{array}$ & $\begin{array}{l}\mathrm{Z}=3.15(\mathrm{P}= \\
0.002)\end{array}$ & $\begin{array}{l}\text { Random } \\
\text { Effect }\end{array}$ \\
\hline $\begin{array}{l}\text { Does the IP guideline } \\
\text { available in your } \\
\text { workplace? }\end{array}$ & $\begin{array}{l}\text { Ethiopia, Sierra } \\
\text { Leone }\end{array}$ & 1582 & $\begin{array}{l}(114)(71)(115)( \\
119)(22)\end{array}$ & $\begin{array}{l}50.95 \quad[40.22, \\
61.67]\end{array}$ & $\begin{array}{l}\mathrm{Tau}^{2}=130.73 ; \mathrm{Chi}^{2} \\
=36.57, \mathrm{df}=4(\mathrm{P}< \\
0.00001) ; \mathrm{I}^{2}=89 \%\end{array}$ & $\begin{array}{l}\mathrm{Z}=9.31(\mathrm{P}< \\
0.00001)\end{array}$ & $\begin{array}{l}\text { Random } \\
\text { Effect }\end{array}$ \\
\hline $\begin{array}{l}\text { Do you practice hand } \\
\text { hygiene which includes } \\
\text { the five movements of } \\
\text { hand hygiene and the six } \\
\text { stages of handwashing by } \\
\text { the respondents involved } \\
\text { in the care of ICU } \\
\text { patients? }\end{array}$ & $\begin{array}{l}\text { Nigeria, Egypt, } \\
\text { Kenya, } \\
\text { Ethiopia, Sierra } \\
\text { Leone }\end{array}$ & 1171 & $\begin{array}{l}(108)(74)(118)( \\
114) \\
(119)\end{array}$ & $\begin{array}{l}41.58 \quad[23.81, \\
59.35]\end{array}$ & $\begin{array}{l}\mathrm{Tau}^{2}=377.68 ; \mathrm{Chi}^{2} \\
=64.73, \mathrm{df}=4(\mathrm{P}< \\
0.00001) ; \mathrm{I}^{2}=94 \%\end{array}$ & $\begin{array}{l}\mathrm{Z}=4.59(\mathrm{P}< \\
0.00001)\end{array}$ & $\begin{array}{l}\text { Random } \\
\text { Effect }\end{array}$ \\
\hline $\begin{array}{l}\text { Do you wear fresh gloves } \\
\text { before examining new } \\
\text { patients? }\end{array}$ & $\begin{array}{l}\text { Nigeria, Egypt, } \\
\text { Ethiopia }\end{array}$ & 1783 & $\begin{array}{l}(108)(74)(114)( \\
109) \\
(110)(48)(113)\end{array}$ & $\begin{array}{l}61.28 \quad[46.64, \\
75.93]\end{array}$ & $\begin{array}{l}\mathrm{Tau}^{2}=365.22 ; \mathrm{Chi}^{2} \\
=547.27, \mathrm{df}=6(\mathrm{P}< \\
0.00001) ; \mathrm{I}^{2}=99 \%\end{array}$ & $\begin{array}{l}\mathrm{Z}=8.20(\mathrm{P}< \\
0.00001)\end{array}$ & $\begin{array}{l}\text { Random } \\
\text { Effect }\end{array}$ \\
\hline $\begin{array}{l}\text { Are you routinely } \\
\text { masked before entering } \\
\text { the intensive care unit? }\end{array}$ & $\begin{array}{l}\text { Nigeria, Egypt, } \\
\text { Ethiopia }\end{array}$ & 1598 & $\begin{array}{l}(108)(74)(114)( \\
109)(115)(113)\end{array}$ & $\begin{array}{l}36.10 \quad[21.11, \\
51.08]\end{array}$ & $\begin{array}{l}\mathrm{Tau}^{2}=314.56 ; \mathrm{Chi}^{2} \\
=68.87, \mathrm{df}=5(\mathrm{P}< \\
0.00001) ; \mathrm{I}^{2}=93 \%\end{array}$ & $\begin{array}{l}\begin{array}{l}\text { Test } \\
\text { overall }\end{array} \\
\text { effect: } \mathrm{Z}= \\
4.72 \quad(\mathrm{P} \quad \\
0.00001)\end{array}$ & $\begin{array}{l}\text { Random } \\
\text { Effect }\end{array}$ \\
\hline $\begin{array}{l}\text { Are you routinely } \\
\text { gowned before entering } \\
\text { the intensive care unit? }\end{array}$ & $\begin{array}{l}\text { Ethiopia, } \\
\text { Nigeria, } \\
\text { Uganda }\end{array}$ & 523 & $(114)(109)(117)$ & $\begin{array}{l}43.81 \quad[25.04, \\
62.58]\end{array}$ & $\begin{array}{l}\mathrm{Tau}^{2}=242.42 ; \mathrm{Chi}^{2} \\
=17.19, \mathrm{df}=2(\mathrm{P}= \\
0.0002) ; \mathrm{I}^{2}=88 \%\end{array}$ & $\begin{array}{l}\mathrm{Z}=4.57(\mathrm{P}< \\
0.00001)\end{array}$ & $\begin{array}{l}\text { Random } \\
\text { Effect }\end{array}$ \\
\hline $\begin{array}{l}\text { Have you routinely worn } \\
\text { goggles before entering } \\
\text { the intensive care unit? }\end{array}$ & $\begin{array}{l}\text { Ethiopia, } \\
\text { Nigeria }\end{array}$ & 1487 & $\begin{array}{l}(114)(109)(115) \\
(110)(113)\end{array}$ & $\begin{array}{l}41.91 \\
79.93]\end{array}$ & $\begin{array}{l}\mathrm{Tau}^{2}=1859.94 \\
\mathrm{Chi}^{2}=504.60, \mathrm{df}= \\
4(\mathrm{P}<0.00001) ; \mathrm{I}^{2}= \\
99 \%\end{array}$ & $\begin{array}{l}\mathrm{Z}=2.16(\mathrm{P}= \\
0.03)\end{array}$ & $\begin{array}{l}\text { Random } \\
\text { Effect }\end{array}$ \\
\hline $\begin{array}{lr}\text { Are you admitted } \\
\text { infection }\end{array}$ & $\begin{array}{l}\text { Nigeria, Egypt, } \\
\text { Ethiopia }\end{array}$ & 540 & $(108)(74)(114)$ & $\begin{array}{l}33.47 \quad[26.59, \\
40.35]\end{array}$ & $\begin{array}{l}\mathrm{Chi}^{2}=1.75, \mathrm{df}=2 \\
(\mathrm{P}=0.42) ; \mathrm{I}^{2}=0 \%\end{array}$ & $\begin{array}{l}\mathrm{Z}=9.54(\mathrm{P} \\
<0.00001)\end{array}$ & fixed \\
\hline
\end{tabular}




\begin{tabular}{|c|c|c|c|c|c|c|c|}
\hline guidelines? & & & & & & & \\
\hline $\begin{array}{l}\text { Do you wash your hands } \\
\text { with soap before patient } \\
\text { care? }\end{array}$ & $\begin{array}{l}\text { Ethiopia, } \\
\text { Nigeria, } \\
\text { Uganda }\end{array}$ & 1176 & $\begin{array}{l}(114)(71)(109)( \\
110) \\
(117)(54)\end{array}$ & $\begin{array}{l}35.86 \\
58.77]\end{array} \quad[12.95$, & $\begin{array}{l}\mathrm{Tau}^{2}=786.17 ; \mathrm{Chi}^{2} \\
=190.83, \mathrm{df}=5(\mathrm{P}< \\
0.00001) ; \mathrm{I}^{2}=97 \%\end{array}$ & $\begin{array}{l}\mathrm{Z}=3.07(\mathrm{P}= \\
0.002)\end{array}$ & $\begin{array}{l}\text { Random } \\
\text { Effect }\end{array}$ \\
\hline $\begin{array}{l}\text { Do you wash your hands } \\
\text { with soap after patient } \\
\text { care/contact with fluid? }\end{array}$ & $\begin{array}{l}\text { Ethiopia, } \\
\text { Nigeria }\end{array}$ & 472 & $(114)(109)(54)$ & $\begin{array}{l}71.62 \quad[39.66, \\
103.58] \quad\end{array}$ & $\begin{array}{l}\mathrm{Tau}^{2}=777.09 ; \mathrm{Chi}^{2} \\
=107.92, \mathrm{df}=2(\mathrm{P}< \\
0.00001) ; \mathrm{I}^{2}=98 \%\end{array}$ & $\begin{array}{l}\mathrm{Z}=4.39(\mathrm{P}< \\
0.0001)\end{array}$ & $\begin{array}{l}\text { Random } \\
\text { Effect }\end{array}$ \\
\hline $\begin{array}{l}\text { Do you wash your hands } \\
\text { without soap before and } \\
\text { after patient care? }\end{array}$ & $\begin{array}{l}\text { Ethiopia, } \\
\text { Nigeria }\end{array}$ & 987 & $(114)(71)(109)$ & $\begin{array}{l}69.56 \quad[49.64, \\
89.47]\end{array}$ & $\begin{array}{l}\mathrm{Tau}^{2}=295.34 ; \mathrm{Chi}^{2} \\
=74.27, \mathrm{df}=2(\mathrm{P}< \\
0.00001) ; \mathrm{I}^{2}=97 \%\end{array}$ & $\begin{array}{l}\mathrm{Z}=6.84(\mathrm{P}< \\
0.00001)\end{array}$ & $\begin{array}{l}\text { Random } \\
\text { Effect }\end{array}$ \\
\hline $\begin{array}{l}\text { Are you knowledgeable } \\
\text { about } \\
\text { prevention? }\end{array}$ & Ethiopia & 1080 & $(114)(71)(22)$ & $\begin{array}{l}73.27 \quad[53.71, \\
92.82]\end{array}$ & $\begin{array}{l}\mathrm{Tau}^{2}=290.60 ; \mathrm{Chi}^{2} \\
=76.42, \mathrm{df}=2(\mathrm{P}< \\
0.00001) ; \mathrm{I}^{2}=97 \%\end{array}$ & $\begin{array}{l}\mathrm{Z}=7.34(\mathrm{P}< \\
0.00001)\end{array}$ & $\begin{array}{l}\text { Random } \\
\text { Effect }\end{array}$ \\
\hline $\begin{array}{l}\text { Do you practice } \\
\text { Recapping syringes? }\end{array}$ & Egypt, Ethiopia & 742 & $(74)(114)(22)$ & $\begin{array}{l}43.41 \quad[23.78, \\
63.04] \quad\end{array}$ & $\begin{array}{l}\mathrm{Tau}^{2}=274.74 ; \mathrm{Chi}^{2} \\
=25.47, \mathrm{df}=2(\mathrm{P}< \\
0.00001) ; \mathrm{I}^{2}=92 \%\end{array}$ & $\begin{array}{l}\mathrm{Z}=4.33(\mathrm{P}< \\
0.0001)\end{array}$ & $\begin{array}{l}\text { Random } \\
\text { Effect }\end{array}$ \\
\hline $\begin{array}{l}\text { Do you know that the } \\
\text { safety box should be } \\
\text { closed/sealed when three } \\
\text { quarters are filled? }\end{array}$ & Ethiopia & 1170 & $(71)(22)(17)$ & $\begin{array}{l}65.80 \quad[44.09, \\
87.51]\end{array}$ & $\begin{array}{l}\mathrm{Tau}^{2}=356.48 ; \mathrm{Chi}^{2} \\
=73.42, \mathrm{df}=2(\mathrm{P}< \\
0.00001) ; \mathrm{I}^{2}=97 \%\end{array}$ & $\begin{array}{l}\mathrm{Z}=5.94(\mathrm{P}< \\
0.00001)\end{array}$ & $\begin{array}{l}\text { Random } \\
\text { Effect }\end{array}$ \\
\hline $\begin{array}{l}\text { Were you exposed to the } \\
\text { risk of needlestick } \\
\text { injuries at least once } \\
\text { during your lifetime? }\end{array}$ & Ethiopia & 791 & $(19)(20)(21)$ & $\begin{array}{l}45.07 \quad[27.93, \\
62.21] \quad\end{array}$ & $\begin{array}{l}\mathrm{Tau}^{2}=191.23 ; \mathrm{Chi}^{2} \\
=13.07, \mathrm{df}=2(\mathrm{P}= \\
0.001) ; \mathrm{I}^{2}=85 \%\end{array}$ & $\begin{array}{l}\mathrm{Z}=5.15(\mathrm{P}< \\
0.00001)\end{array}$ & $\begin{array}{l}\text { Random } \\
\text { Effect }\end{array}$ \\
\hline $\begin{array}{l}\text { Do you use alcohol swab } \\
\text { after needle stick? }\end{array}$ & $\begin{array}{l}\text { Egypt, Kenya, } \\
\text { Ethiopia }\end{array}$ & 666 & $(74)(118)(114)$ & $\begin{array}{l}63.80 \quad[47.85, \\
79.74]\end{array}$ & $\begin{array}{l}\mathrm{Tau}^{2}=177.77 ; \mathrm{Chi}^{2} \\
=20.30, \mathrm{df}=2(\mathrm{P}< \\
0.0001) ; \mathrm{I}^{2}=90 \%\end{array}$ & $\begin{array}{l}\mathrm{Z}=7.84(\mathrm{P}< \\
0.00001)\end{array}$ & $\begin{array}{l}\text { Random } \\
\text { Effect }\end{array}$ \\
\hline
\end{tabular}




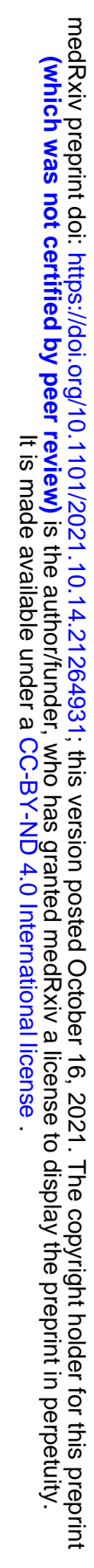

